\title{
1 Achievable Future Conditions as a Framework for Guiding Forest Conservation and
}

\section{Management}

3 S.W. Golladay ${ }^{1}$, K.L. Martin ${ }^{2}$, J.M. Vose $^{3}$, D.N. Wear ${ }^{4}$, A.P. Covich ${ }^{5}$, R.J. Hobbs ${ }^{6}$, K.D.

$4 \quad$ Klepzig $^{7}$, G.E. Likens ${ }^{8}$, R.J. Naiman ${ }^{9}$, and A.W. Shearer ${ }^{10}$

6 We contend that traditional approaches to forest conservation and management will be

7 inadequate given the predicted scale of social-economic and biophysical changes in the $21^{\text {st }}$

8 century. New approaches, focused on anticipating and guiding ecological responses to change,

9 are urgently needed to ensure the full value of forest ecosystem services for future generations.

10 These approaches acknowledge that change is inevitable and sometimes irreversible, and that

11 maintenance of ecosystem services depends in part on novel ecosystems, i.e., species

12 combinations with no analog in the past. We propose that ecological responses be evaluated at

13 landscape or regional scales using risk-based approaches to incorporate uncertainty into forest

14 management efforts with subsequent goals for management based on Achievable Future

15 Conditions (AFC). AFCs defined at a landscape or regional scale incorporate advancements in

16 ecosystem management, including adaptive approaches, resilience, and desired future conditions

17 into the context of the Anthropocene. Inherently forward looking, ACFs encompass mitigation

18 and adaptation options to respond to scenarios of projected future biophysical, social-economic,

19 and policy conditions which distribute risk and provide diversity of response to uncertainty. The

20 engagement of science-management-public partnerships is critical to our risk-based approach for

21 defining AFCs. Robust monitoring programs of forest management actions are also crucial to

22 address uncertainty regarding species distributions and ecosystem processes. Development of

23 regional indicators of response will also be essential to evaluate outcomes of management 
24 strategies. Our conceptual framework provides a starting point to move toward AFCs for forest

25 management, illustrated with examples from fire and water management in the Southeastern

26 United States. Our model is adaptive, incorporating evaluation and modification as new

27 information becomes available and as social-ecological dynamics change. It expands on

28 established principles of ecosystem management and best management practices (BMPs) and

29 incorporates scenarios of future conditions. It also highlights the potential limits of existing

30 institutional structures for defining AFCs and achieving them. In an uncertain future of rapid

31 change and abrupt, unforeseen transitions, adjustments in management approaches will be

32 necessary and some actions will fail. However, it is increasingly evident that the greatest risk is

33 posed by continuing to implement strategies inconsistent with current understanding of our novel

34 future.

36 Keywords: forest management, conservation, ecosystem services, novel ecosystems, achievable

37 future conditions, Southeastern United States

39 Author affiliations:

40

${ }^{1}$ J.W. Jones Ecological Research Center, 3988 Jones Center Dr, Newton GA 39819 USA (sgollada@jonesctr.org - Corresponding Author)

${ }^{2}$ USDA Forest Service, Center for Integrated Forest Science and Synthesis, Research Triangle Park NC 27709, USA (katie_martin@ ncsu.edu)

${ }^{3}$ USDA Forest Service, Center for Integrated Forest Science and Synthesis, Campus Box 8008, North Carolina State University, Raleigh NC 27695 USA (jvose@ fs.fed.us)

${ }^{4}$ USDA Forest Service, Center for Integrated Forest Science and Synthesis, Campus Box 8008, North Carolina State University, Raleigh NC 27695 USA (dwear@ fs.fed.us)

${ }^{5}$ Odum School of Ecology, 140 E Green Str, University of Georgia, Athens GA 30602 USA (alanc@uga.edu) 
$51{ }^{6}$ School of Plant Biology, 35 Stirling Hwy, University of Western Australia (M090), Crawley

$52 \quad$ WA 6009, Australia (richard.hobbs@uwa.edu.au)

$53 \quad{ }^{7}$ USDA Forest Service, Southern Research Station, 200 WT Weaver Blvd, Asheville NC 28804

$54 \quad$ USA (kklepzig@ fs.fed.us)

$55{ }^{8}$ Cary Institute of Ecosystem Sciences and Department of Ecology and Environmental Biology,

56 University of Connecticut, Storrs; 2801 Sharon Turnpike, PO Box AB, Millbrook NY 12545

57 USA (likensg@ caryinstitute.org)

$58{ }^{9}$ School of Aquatic and Fishery Sciences, University of Washington and CENRM, University of

59 Western Australia, 133 Wilson Lane, Friday Harbor WA 98250 USA (naiman@uw.edu)

$60{ }^{10}$ School of Architecture - Center for Sustainable Development, The University of Texas at

61 Austin, 310 Inner Campus Drive, B7500, Austin TX 78712 USA

62 (ashearer@austin.utexas.edu)

63

64

65

\section{1. Introduction}

67 The future is increasingly uncertain due to the rapid and compounded environmental, economic,

68 and social changes that characterize the so-called Anthropocene, the geological epoch dominated

69 by human modification of the Earth System (Steffan et al. 2007). High rates of landscape

70 modification and species extinctions are unprecedented, and few, if any, ecosystems remain

71 beyond the influence of human activity (e.g., Likens 2001, Seasted et al. 2008, Hobbs et al.

72 2009). Modern landscapes are social-ecological matrices of patches ranging from "natural/wild"

73 to "intensive commodities-oriented" to "urban" (Hobbs et al. 2014). Novel ecosystems -- the

74 product of direct or indirect human activity-- are increasingly prevalent and are often

75 characterized by species assemblages and biophysical conditions with no analog in the past

76 (Hobbs et al. 2006). The combined effects of changing climate and land-use, habitat

77 fragmentation, species loss and introductions, and altered nutrient and hydrologic cycles at times

78 exceed the ability of contemporary ecosystems to maintain their structure and function. Such 
79 disruptions can result in rapid unanticipated transitions and irreversible thresholds, which have

80 significant social and ecological consequences (see Research Alliance Thresholds Database for

81 examples, http://www.resalliance.org/index.php/thresholds_database). At the same time, there

82 are societal expectations that ecosystems can and will be restored or rehabilitated to functional

83 states, even while climate change, population growth, water diversion, the proliferation of

84 chemicals and numerous other environmental changes impose additional burdens in ways that

85 are not adequately understood (Naiman 2013). Indeed, a primary goal of ecosystem

86 management is to sustain ecosystem structure and function (Christensen et al. 1996). However,

87 we contend that ongoing changes will in some cases exceed our ability to sustain existing

88 ecosystems, and in such cases, a shift in focus to mitigation and adaptation for ecosystem

89 services will be necessary and therefore produce "novel" ecosystems (e.g., Millar et al. 2007,

90 Hobbs et al. 2014).

92 The rate and magnitude of environmental and socio-economic change expected over the next

93 several decades will require innovative conservation and management perspectives, as these

94 anthropogenic changes will alter (e.g., increase or decrease) the ability of ecosystems to provide

95 ecosystem services (Hobbs 2014, AIBS, actionbioscience.org/environment/esa.html). Ecosystem

96 services are values associated with human well-being and are comprised of needs (i.e., life

97 sustaining) and desires (i.e., quality of life sustaining), with both tightly tied to ecosystem

98 structure and function. The capacity to maintain or enhance these services is a significant 
99 concern, as reductions hold negative and in some cases, potentially dire consequences for human

100 well-being (e.g., www.millenniumassessment.org).

102 Although many of the concepts presented in this paper can be applied to a wide range of

103 ecosystems, our focus is primarily on forests. Forests are an especially critical component of the

104 modern landscape, providing diverse services such as wood and fiber, climate regulation, carbon

105 storage, biodiversity support, and regulation of water yields and quality (FAO and JRC 2012,

106 Agrawal et al. 2013, Haddad et al. 2015). Current approaches to forest management in areas

107 dominated by private land ownership are generally fragmented and uncoordinated. While

108 management goals may be intended to ensure productivity, environmental quality, and

109 conservation of biodiversity, management approaches are often limited in their ability to protect

110 key ecosystem services given the rate and scale of biophysical and social-economic changes. We

111 attribute this deficiency, at least in part, to an outdated view of ecosystems and the Earth System

112 as static or inherently stable rather than dynamic (Pickett et al. 1992, Milly et al. 2008). New

113 approaches focused on anticipating and guiding ecological responses to change are urgently

114 needed to ensure ecosystem services for future generations. This need will likely require

115 challenging some widely accepted principles of forest management and restoration, revising and

116 expanding long-held guidelines and best management practices, and reappraisal of current

117 regulations and laws. For example, focusing conservation efforts on public lands, local preserves,

118 protection of rare species assemblages, and restoration of historic forest ecosystems may prove 
119 insufficient. Change is inevitable and might often be irreversible, so the provision of ecosystem

120 services will depend, in part, on the development of novel ecosystems and the emergence of

121 regionally coordinated forest conservation strategies and management approaches that consider

122 both public and private land (Dale et al. 2000, Seastedt et al. 2008, Hobbs et al. 2013, Rieman et

123 al. 2015). Managing in the Anthropocene builds on many of the concepts of ecosystem

124 management (Christensen et al. 1996), but incorporates long-term risk and uncertainty, and

125 recognizes that future biophysical and social-economic conditions constrain desired management

126 outcomes. As a starting point, we propose the following tenets:

127

128 1. Science-Management-Public partnerships as a foundation for conservation

129 strategies. It has long been acknowledged that ecological dynamics operate at scales

130 that are independent of ownership and political boundaries, so the effectiveness of

131 conservation strategies will depend on the spatial arrangement of decisions at multiple

132 scales (Christensen et al. 1996). However, this challenge presented by ecosystem

133 management has yet to be resolved. Landscape assessments and management planning

134 that cross these boundaries and incorporate stakeholder concerns and desires may

135 provide the only means of anticipating the cumulative effects of multiple drivers

136 operating at various scales. The emergence of novel ecosystems also creates challenges

137 that span traditional management and technical boundaries (terrestrial, aquatic, game

138 and non-game wildlife, endangered species, etc.), and a need for integrated

139 management across these boundaries. 


\section{A risk-based approach is required to assess current conditions and develop} impossible to provide rigorously quantified estimates of future uncertainty for decisionmaking (Carpenter et al. 2009). However, there is increasing certainty that future biophysical conditions will continue to diverge from the past. Further, risks can be quantified by using technical information to develop possible future scenarios (risk assessment) using best available information and accounting for uncertainty. Thus, effective conservation planning and policies must include the envelopes of potential future social-economic and biophysical conditions. We call these envelopes 'Achievable Future Conditions' AFCs (see below), and their development moves beyond projections of future biophysical conditions. The AFCs should be designed within the boundaries of social acceptance and capacity for decision-making. AFCs are intended to facilitate social and ecological adaptive capacity to respond to uncertain, even unforeseen, conditions (e.g., Gunderson 2000, Chapin et al. 2009). Applying a risk-based framework to alternative future scenarios can help identify potential problems and limitations, improving the likelihood that conservation objectives are achievable. conservation and management actions. The primary objective of the AFC approach 
is to identify an envelope of achievable ecosystem service futures that incorporate current understanding of projected biophysical constraints, social-economic demands, and political realities of land ownership and development. From this foundation, risk management approaches can be used to consider and prioritize management actions that can mitigate undesirable conditions or provide adaptive responses to reduce adverse consequences of anticipated change (Yohe and Leichenko 2010). Mitigation and adaptation distribute risk and provide diversity of response in the face of uncertainty. The process is inherently iterative, as new information becomes available, strategies for mitigation and adaptation can be revised or reprioritized as needed (Yohe and

172 We apply a conceptual approach to conservation and management that examines projected 173 environmental changes and ecological responses using the southeastern United States as a

174 template. At the core of our approach is the delineation of AFCs that constrain outcomes within

175 the boundaries set by future biophysical, social-economic and political scenarios. The dominance

176 of diverse private landowners, abundance of forest area and forestry operations, and the

177 dynamics of land uses make the southeastern U.S. challenging and illustrative example.

\section{2. Developing Conservation Strategies}

180 Our conceptual approach emphasizes that human population growth and development will be 181 rapid, and as a result, biophysical and social-economic systems will continue to change in ways 
182 that are uncertain and may result in unprecedented or novel conditions. To ensure that forest

183 ecosystems will continue to provide essential ecosystem services, planning will need to apply

184 risk-based scenarios of future conditions. By necessity these strategies will be forward looking,

185 interdisciplinary, large scale, and include mitigative (actions that reduce vulnerability) and

186 adaptive (actions that cope with consequences) elements. In the following section, we outline

187 critical elements that guide forest responses to rapid environmental and social-economic

188 changes, and provide a conceptual model for the process we propose (Figure 1). We begin by

189 describing the critical elements required to convert our tenets into effective strategies, provide

190 scenario-based projections for future biophysical and social conditions in the southeastern U.S.,

191 discuss the challenges that remain to implement our strategies, and use natural resource

192 management case studies to demonstrate how strategies could be applied to anticipate and

193 manage ecological responses.

195 2.1. Element 1: Science-Management-Public partnerships are the foundation for successful

196 conservation strategies.

198 Partnerships between researchers, managers and the public are foundational to identifying

199 priorities for ecosystem services, where meaningful changes and/or scarcities of ecosystem

200 services might arise. Without communication among scientists, managers, and stakeholders at

201 appropriate spatial and temporal scales, the ability to understand ecosystem service tradeoffs will

202 be limited. The ecosystem services that societies depend upon are often not well aligned with 
203 political boundaries, so coordination across jurisdictional borders is imperative. Because they are

204 not traded and are by-products of management for other services (i.e., classic production

205 externalities) most ecosystem services are unlikely to be produced at socially-optimal rates.

207 Stakeholder engagement remains an enormous challenge (e.g., Reed et al. 2009) especially in

208 mixed ownership settings of the Southeast, where the autonomy of landowner choices creates

209 difficulties for coordinating management strategies to achieve regional benefits. Large-scale

210 conservation strategies will be most successful when stakeholders are engaged in developing

211 priorities and understand how risks could be reduced and outcomes for local conditions enhanced

212 through coordinated regional management approaches. Research into the potential benefits and

213 costs of institutional mechanisms, including regulation, or landowner incentives, easements, and

214 trading between landowners and ecosystem service consumers is needed to encourage the

215 coordinated decision-making that can lead to better ecosystem service outcomes. Existing

216 institutions may need to be modified to support coordinated activities within and among

217 constituents to focus on landscape or regional outcomes.

218

219 2.2. Element 2: A risk-based approach is required to develop and manage conservation

220 strategies in the face of future uncertainty.

222 There is a growing consensus that future forest dynamics will be altered in ways we will not

223 anticipate, resulting in outcomes that will challenge our understanding (Lindenmayer and Likens 
224 2010). Beyond ecological dynamics, our understanding of how to guide the responses of

225 coupled social-ecological systems to sustain ecosystem services is a continually evolving area of

226 research (Carpenter et al. 2009). Management planning and evaluation of ecosystem services are

227 predominantly based on current and/or historic conditions, and goals are set to sustain the

228 existing ecosystem structures and functions that support them (Christensen et al. 1996)

229 However, given the pace of climate and land-use changes, historical conditions and ecological

230 communities might become increasingly improbable (e.g., Maes et al. 2012). Current conditions

231 are best viewed as baselines for projecting future scenarios and developing risk management

232 strategies (Figure 1), but this approach is seldom applied to projections for the provision of

233 ecosystem services at relevant scales (Iverson et al. 2012, Wear and Greis 2013). The uncertainty

234 of any specific future projection may be high, but a scenario-based approach generates an

235 envelope around the range of possible forest futures (Wear and Greis 2013) from which risk can

236 be assessed.

237

238 Assessing risk can help define outcomes and guide prioritization of potential problems and

239 conservation strategies at large spatial scales. Risk can be described as the product of the

240 frequency of a "hazardous" event (e.g., drought, storms, wildfire) and the consequences of the

241 event (IPCC 2014, Yohe and Leichenko 2010), where "hazardous" is defined as an event whose

242 frequency or severity is sufficient to cause undesirable outcomes. Characterizing risk requires

243 consideration of the physical, environmental, and socioeconomic factors that determine the

244 ability to resist or recover from a hazardous event, referred to as vulnerability. For example, high 
245 severity events (e.g., catastrophic flooding and landslides following extreme rainfall, forest

246 wildfires during droughts) are always high risk, even when the likelihood of occurrence is low.

247 Conversely, low severity events (e.g., tree growth reduction due to short-term drought) generally

248 are low risk, even when the likelihood of occurrence is high. Risk management involves a

249 variety of mitigative and adaptative options that reduce risk or vulnerability to acceptable levels

250 (IPCC 2007, Yohe and Leichenko 2010). Examples using this bivariate approach in the

251 ecological literature are rare (Iverson et al. 2012); however, implementing a risk-based

252 framework for management simply requires that assessments are based on projected frequency

253 and estimated consequences (Ojima et al. 2012). The utility of risk-based approaches has been

254 recognized in forest management (e.g., Ojima et al. 2014).

255

256 Quantifying risks at fine spatial and temporal scales is likely to be highly uncertain, and in cases

257 where there is insufficient knowledge, it may be necessary to apply qualitative rather than

258 quantitative analyses (e.g., IPCC 2007, Richter et al. 2011, Melillo et al. 2014). Both quantitative

259 and qualitative information can be used to determine vulnerabilities as well as acceptable levels

260 of risk in response to the changing biophysical and socioeconomic drivers.

262 2.3. Element 3. Achievable Future Conditions provide the foundation for prioritizing

263 conservation and management actions. 
265 A cornerstone for conservation planning has been the identification of desired future conditions

266 (DFC). Guided by historical endpoints and legal requirements like the Endangered Species Act

267 in the US, DFCs typically include maintenance or restoration to a historical condition of existing

268 species, communities or ecosystems. Although the DFC approach has proven useful, it fails to

269 address how rapidly changing biophysical and social ecological conditions could lead to novel

270 conditions at a landscape or regional scale with unattainable historical endpoints. For example, a

271 DFC for a restored freshwater wetland in coastal areas subject to sea level rise and saltwater

272 intrusion is not feasible (Ardón et al. 2013). Instead, we propose more forward looking DFCs

273 that grant equal or greater weight to projected future scenarios of biophysical and social-

274 economic change (Prato 2008); more appropriately termed "Achievable Future Conditions"

275 (AFC). Defining AFCs requires a science-management-public partnership to develop social-

276 economic needs and ecological possibilities within the risk-based and scenario building

277 framework. The AFCs along with the identification of vulnerabilities and thresholds for

278 acceptable risk can be used to determine the goals for management.

280 To be successful at large spatial scales, management actions to achieve AFCs will require

281 widespread acceptance and application. The best analogy is the current implementation of best

282 management practices (BMP) to minimize or mitigate impacts of timber harvesting and site

283 preparation on water quality and site productivity (Prud'homme and Greis 2002, Aust and Blinn

284 2004). We build upon the concept of BMPs, but our discussion extends beyond the current 285 scope and authority of most water-based BMP programs in the Southeast. Our suggestion is that 
286 the scope of BMPs should be broadened to include management practices that guide ecological

287 change to attain AFCs. Broadening also implies an ongoing need for monitoring of BMPs

288 (discussed below) for efficacy and the establishment of adaptive mechanisms for adjusting

289 practices to reflect new and anticipated ecosystem conditions (e.g., Westgate et al. 2013). These

290 new BMPs will need to include management options that address suites of ecosystem services

291 and the potential tradeoffs among them, such as regional water yields or climate buffering

292 (Bagley et al. 2014). For BMPs to be effective, they must be consistently implemented at

293 regional scales. Further, it should be noted that while BMPs can be effective for guiding

294 management toward AFCs, some problems may be resolved only through elimination of certain

295 practices altogether, implying a need to structure compensation for landowners, perhaps through

296 a payment/trading system within the relevant landscape.

298 Determination of BMP effectiveness requires monitoring to assess if desired outcomes are

299 achieved. Hence, continuous monitoring of physical, biological, and social conditions will be

300 critical to ensure that ecosystem service based management goals are attained. Monitoring will

301 also allow approaches to be modified as priorities and evaluations for AFCs shift in response to

302 changing values and/or updated future forecasts. This evaluation process will require substantial

303 investment in "on-the-ground" environmental monitoring (Lindenmayer and Likens 2010, Fekete

304 et al 2015). Remote sensing can serve some monitoring needs (Hargrove et al. 2009, Famiglietti

305 et al. 2015), but it has limitations in the types of parameters that can be monitored (Kerr and

306 Ostrovsky 2003, Pettorelli et al. 2005, Arvor et al. 2013). Existing and emerging networks (e.g., 
307 Long Term Ecological Research (LTER), Long Term Agroecosystem Research (LTAR),

308 National Ecological Observatory Network (NEON), Global Lake Ecological Observatory

309 Network (GLEON)) and new remote sensing platforms (e.g., GRACE; Thomas et al. 2014,

310 Reager et al. 2014) may also be useful in meeting some landscape and continental scale

311 monitoring needs (Kao et al. 2012, McDowell 2015, Schimel and Keller 2015), but these

312 networks remain largely untested with regards to detecting large scale changes in response to

313 management actions. In addition, emerging networks do not directly address change in forests,

314 particularly on private land. Although not focused on detecting responses to specific

315 management actions, the United Forest Service Forest Inventory and Analysis Program has

316 provided a critical database for assessing changes in forest condition (Woodall et al. 2011). The

317 success of programs such as data on bird populations generated by the Audubon Society's

318 Christmas Bird Count indicate the value of citizen science to meet some of these data needs

319 (Dickenson et al. 2012). Citizen science programs also involve and raise awareness among

320 stakeholders on conservation issues (Aceves-Bueno et al. 2015).

\section{3. The Southeastern Template}

323

324 In this section, we characterize the social and ecological complexity of the Southeastern US and

325 examine future projections for the region as a guide for developing scenario-based management

326 actions. We define the Southeast as the 13 state region included in the Southern Forest Futures 
327 Assessment (Wear and Greis 2013), extending from Virginia and Kentucky, south to Florida and

328 west to Texas and Oklahoma.

330 3.1. A Region of High Social and Ecological Complexity

331 The Southeastern region is dominated by private land ownership and highly diverse forests,

332 streams, rivers, and wetlands. Forests are the dominant land cover type, exceeding $65 \%$ in some

333 states. One third of the private forest lands are under corporate ownership, and these lands are

334 experiencing a rapid shift from ownership and management by integrated forest management

335 companies to real-estate investment trusts (REITs) and timber investment management

336 organizations (TIMOs). This shift toward REITs and TIMOs, which can divest rapidly, makes

337 land ownership and management more difficult to forecast. The remaining two-thirds of the

338 private forest land is owned by individuals or families, who typically lack long-term

339 management plans (Butler and Wear 2013). Developing and implementing management plans is

340 further challenged by the size of landholdings, with an average family holding of less than 12 ha

341 and trending smaller as land is passed down to multiple heirs (Butler and Wear 2013).

342

343 The abundance of small, private landholdings creates a mosaic of developed areas adjacent to

344 wildlands, with up to $22 \%$ of the Southeastern landscape included in wildland-urban interface

345 (WUI) (Zhang et al. 2008). The greatest extent of WUI extends from Virginia to South Carolina,

346 due to development outside mid-sized cities such as Columbia, SC (Zhang et al. 2008, see 
347 below). Expansion of WUI causes habitat fragmentation, biodiversity loss, and increases

348 wildfire risk (Radeloff et al. 2005, Haddad et al. 2015).

350 With an abundance of terrestrial and aquatic habitats, the Southeast is noted for biological 351 richness and high productivity (Burr and Mayden 1992, Neves et al. 1997, Wear and Greis

352 2013), providing diverse ecosystem services (www.teebweb.org). The Southeast leads the nation 353 in timber production, a well-quantified ecosystem service (Wear and Greis 2013). Payments for

354 other forest-based services, including biodiversity (conservation easements and banks, wildlife

355 viewing, and hunting), carbon offsets, and bundled services (e.g., Wetland Reserve Program that

356 provides multiple services) totaled \$1.7-\$1.9 billion across the US from 2005-2007 (Mercer et al.

357 2011). The greatest payment rates occurred in the Southeast, particularly in Georgia, Florida and

358 Louisiana (Mercer et al. 2011). Incentive programs for water resources are frequently provided

359 to agricultural landowners, but payments for conservation measures or water quality trading

360 programs are difficult to estimate on regional scales (Mercer et al. 2011).

362 The major river systems in the southeastern U.S. are influenced by multiple landowners and land 363 uses, across diverse political jurisdictions, and have varying stakeholder interests. Municipal,

364 industrial, and power generation are the predominant drivers of water management programs;

365 however, most drinking water in the Southeast U.S. is derived from surface water sources

366 (Caldwell et al. 2014). Water quality guidelines for large rivers are set through federal

367 regulation and administered by states (i.e., Clean Water Act and NPDS permitting). Adjacent 
368 land use has a large effect on patterns of runoff and water quality. Non-point source runoff is

369 often unregulated on private lands and Best Management Practices (BMP's) are voluntary and

370 not always implemented, particularly for smaller streams (Shortle and Horan 2013). Thus,

371 individual landowner management decisions can have a large effect on runoff into stream

372 reaches crossing the landowner's property. Many larger rivers in the Southeast are regulated by

373 impoundments, whose operating authority and procedures are under control of the US Army

374 Corps of Engineers or other agencies (Benke 1990).

375

376 There is very little practical coordination of management actions at regional scales in the

377 Southeast, despite the objective of "all lands" management approaches by some agencies and

378 conservation groups (Table 1). Notable exceptions include a relatively new effort at range-wide

379 restoration of longleaf pine. Current conservation and knowledge transfer programs are

380 developed and implemented by organizations operating at different scales, sometimes with

381 contrasting objectives and guiding principles. For example, public land management plans

382 emphasize a spectrum of goals, from a broad complement of multiple uses (e.g., National

383 Forests, US Forest Service (USFS)) to long-term protection (e.g., US National Park Service, or

384 Wilderness Areas). Management plans for large private landowners (e.g., The Nature

385 Conservancy, forest industry, land trusts, hunting preserves) typically focus on a narrower set of

386 goals specific to institutional objectives. Goals and objectives may be narrower still for small

387 non-industrial private forest landowners. Communication and knowledge transfer in the

388 Southeast derives from a culture of independence and a strong southeastern legacy of private 
property rights, therefore, is often site-specific and based on local experience. This situation

390 suggests that private landowner participation in coordinated, large-scale conservation efforts is a

391 key challenge requiring innovative strategies to incentivize engagement (Wear and Greis 2013).

\section{3.2. Scenarios for the Future}

394 Projections for the Southeast indicate a future climate that is hotter with more variable

395 precipitation (IPCC 2014). Although precipitation projections are uncertain, greater evaporative

396 loss from increased temperatures is expected to increase water stress (Liu et al. 2013a, Lockaby

397 et al. 2013). The growing human population will rely on an increasingly urbanized landscape for

398 ecosystem services, suggesting the risk of ecosystem service losses or disruptions is increasing

399 (Wear and Greis 2013). Climate models project steady warming across the region, though at

400 varying rates and with subregional differences (IPCC 2007, McNulty et al. 2013). Temperatures

401 are projected to increase between 0.5 and $>3.5 \mathrm{C}$ over the next 50 years, with greater increases in

402 the western part of the region. Precipitation projections vary across models, suggesting

403 potentially high uncertainty. As the climate changes, estimates indicate rapid land use- land

404 cover (LULC) changes due to increasing population, with 12- 17 million ha of new development

405 by 2060 (Wear and Greis 2013). Projected loss of rural land ranges from 4 to 9 million ha (6.5 -

40613.1 percent) for forest, and 2 to 7 million ha (6 - 19 percent) for agriculture. Development and

407 population growth are expected to be greatest at the periphery of urban centers, particularly in

408 the Piedmont of the Southern Appalachian Mountains from Raleigh NC to Atlanta GA, and

409 along the Atlantic and Gulf of Mexico coastal zones (Figure 2, Wear and Greis 2013, Terando et 
410 al. 2014). Scenarios with high economic growth result in more urbanization spread across a

411 larger area (Figure 2). Increasing urban populations are correlated with increasing real incomes;

412 however, the economic conditions in depopulating rural areas are likely to decline, increasing the

413 vulnerability of rural communities to extreme events and reduction of ecological services

414 (Gaither et al. 2011). Differences in economic position and general perspectives on land use

415 (rural-utilitarian vs. urban-aesthetic as an example) suggest both economic and political tensions

416 between stakeholders in contrasting segments of the Southeastern landscape.

418 Projections of forested LULC in the Southeast depend on population- and income-growth drivers

419 as well as agricultural and timber prices. Until recently, forest losses associated with

420 development were offset by afforestation of marginal agricultural land. Recent projections

421 indicate agricultural LULC will stabilize or even increase due to strong future agricultural

422 markets (Wear and Greis 2013). Forest losses are projected to be greatest from northern Georgia

423 through North Carolina and into parts of Virginia (Figure 3). Other areas of projected

424 concentrated forest loss are the Atlantic Coast, along the Gulf of Mexico, and outside of

425 Houston, TX. Forest type is particularly responsive to market conditions, with projections

426 indicating an increasing trend in planted pines that began in the 1950's (Wear and Greis 2013).

427 Planted pines currently occupy almost 16 million ha, or $19 \%$ of the 83 million ha of forest in the

428 Southeast (Wear and Greis 2013, Klepzig et al. 2014). Projections of urbanization and timber

429 prices suggest that by 2060 , planted pines could increase by 11.3 million ha to 27.3 million ha 
430 (34\% of forest area), replacing much of the remaining natural (non-plantation) pine forest (Wear 431 and Greis 2013).

433 Scenarios of future climate and land use suggest forest conservation and management challenges 434 will increase in the Southeast (Wear and Greis 2013). The region faces a future of increasing 435 fragmentation, loss of deciduous forest area in the Piedmont and Southern Appalachians, and 436 potential conversion of natural forest to pine plantations in the Coastal Plain. These changes

437 create uncertainty for important ecosystem services including biodiversity conservation,

438 maintenance of hydrologic function, carbon sequestration, and climate buffering (Weir and Greis

439 2013). Responding to change will require new thinking and strategies. For example, future

440 forests may be subject to large-scale severe wildfires, which have not been a primary concern in

441 the past due to management including prescribed fire (Melvin 2012). Predicted hotter conditions

442 and thus, increased Keetch-Byram Drought Index (KBDI) seem likely to increase wildfire risk

443 (Liu et al. 2013a, Figure 4), causing concerns for the safety and health of an expanding

444 population of the WUI and in depopulating rural areas. The confluence of population growth,

445 urbanization, climate change, and loss/fragmentation of forests will also increase the water

446 supply stress (water demand/water supply) between 10-100\% throughout much of the Southeast

447 (Figure 5).

448

449 4. Applying the Framework to Conservation Challenges in the Southeast US

450 
451 In the following section, we use case studies focused on wildfire risk and water scarcity to

452 explore how our framework could be used to develop and attain AFCs in a real-world setting.

453 Characterizing current conditions is a logical starting point for the process. In the examples that

454 follow, regional drought conditions caused undesirable events (wildfires and exceptionally low

455 stream flows). These observed events, along with climate, land use, and population projections,

456 have created concerns about future risk and exposed vulnerabilities to both stakeholder and

457 management communities. We discuss these case studies in the context of our conceptual model

458 and framework, not to criticize past efforts, but to show how regional conservation strategies and

459 actions might be enhanced to address these concerns.

460

\section{5. Fire Management and the Georgia Bay Complex Wildfires}

462 The Southeast experiences more wildfire than any other region of the country, averaging 45,000

463 fires a year over the six year period from 1997-2003 (Mitchell et al. 2014). Typically, wildfires

464 are not severe or large, as many Southeastern ecosystems are adapted to short fire return intervals

465 that reduce fuel loads (Liu et al. 2013a). The Southeast also has a strong tradition of prescribed

466 fire management, implementing more burns than other regions combined (Melvin 2012).

467 Prescribed burns have historically been implemented for management of fire-dependent

468 biodiversity, including game species. Despite regular fuels management, Southeastern wildfires

469 destroy more structures than in other regions and can lead to substantial timber losses for

470 affected landowners (Stanturf and Goodrick 2013). Projections for climate and land use in the

471 Southeast indicate wildfires will be more frequent, intense, and occur over a fire season that will 
472 be extended by 1-3 months (Liu et al 2013a, Liu et al. 2013b). These conditions suggest that

473 wildfires will burn under more extreme conditions and fire frequency will increase in ecosystems

474 with longer fire return intervals, including wetlands that historically burn only during significant

475 droughts (Stanturf and Goodrick 2013). The risk imposed by future wildfire will be compounded

476 because of projected expansion of WUI and dispersed rural housing (Gaither et al. 2011, Liu et

477 al. 2013a, Zhang et al. 2013). As wildfire risk increases, fuel management will be constrained

478 because fewer days will meet criteria for prescribed fire implementation (Liu et al. 2013a,

479 Mitchell et al. 2014). Recent wildfires in Georgia and Florida provide useful guidelines for

480 potential future wildfire in the Southeastern U.S., and we use the Greater Okefenokee region as

481 an application of our risk-based management framework (Figure 6).

482

483 In 2007, the Georgia Bay Complex Fires (including the Sweat Farm Road Fire, Big Turnaround

484 Fire Complex and the Bugaboo Scrub Fire) burned 242,800 ha across federal, state and private

485 lands under severe drought conditions. The fires exhibited novel, erratic fire behavior, including

486 flame lengths as high as $30 \mathrm{~m}$ (Edwards et al. 2013). Timber losses on private lands were in

487 excess of $\$ 58$ million (Mitchell et al. 2014). Smoke from the fires degraded air quality from

488 Mississippi to North Carolina (Odman et al. 2007, Mitchell et al. 2014) and caused the temporary

489 closure of two interstate highways in southern Georgia and northern Florida (I-10 and I-75)

490 (Edwards et al. 2013). Adjacent communities were at particularly high risk, as many of them

491 had been identified as economically vulnerable (Gaither et al. 2011). Only four years later, the

4922011 Honey Prairie Complex Fire became the second largest in the Okefenokee region's history 
493 (125,129 ha) (http://www.fws.gov/okefenokee/HoneyPrairieArchive.html). The estimated

494 historic return interval for such large fires was approximately 150 years (Yin 1993).

496 5.1. Science-Management-Public partnerships as a foundation for conservation strategies

497 Collaboration and coordination are particularly critical for fire management in the Southeast

498 because of fragmented land ownership, high WUI, economically vulnerable rural residents, and

499 valuable, fire-sensitive timber resources. The Greater Okefenokee Association of Landowners

500 (GOAL) was formed between US Fish and Wildlife Service, state agencies from Georgia and

501 Florida, and private landowners to coordinate fire responses, motivated by an active wildfire

502 season in 1994 (Table 1). While it includes representatives from adjacent rural communities,

503 GOAL would need to expand to facilitate wildfire mitigation for socio-economically vulnerable

504 rural residents, including renters and their properties, to mitigate wildfire risk (Gaither et al.

505 2011). Further, GOAL does not currently include significant participation from the scientific

506 research community, which could facilitate estimates of future fire risk, and move the

507 organization toward more anticipatory strategies.

508

509 5.2. A risk-based approach to assess current conditions and develop conservation strategies in

510 the face of future uncertainty -

511 Risk assessment and prioritization are key goals of the Stewardship and Fireshed Assessment

512 (SFA) process, which is increasingly implemented on public lands in the West (Bahro et al.

513 2007). The SFA uses a collaborative approach incorporating expert opinion, stakeholder 
514 involvement, and simulation modeling of management outcomes to prioritize landscape-scale

515 wildfire risk reduction (Bahro et al. 2007). Landscapes are delineated into firesheds, usually

516 several times the spatial extent of large, severe wildfires (Bahro et al. 2007, North et al. 2012).

517 Delineations are based on historic fire data, fuels, LULC including WUI, expert opinion and

518 stakeholder involvement. Coordinated strategies for fire and fuels management are developed

519 and implemented using firesheds as management units (Bahro et al. 2007, North et al. 2012).

521 Application of fireshed management concepts in our conservation and management framework

522 (Figure 6) begins with a fuels assessment to establish baseline risk conditions. The Southern

523 Wildfire Risk Assessment Tool is a potentially important resource to establish baseline

524 conditions (www.southernwildfirerisk.com) that the scientific community could add to as a

525 resource for GOAL. The current map indicates that the Okefenokee fireshed includes areas of

526 moderate and high severity fire risk, primarily in the uplands. Established baselines can then be

527 incorporated into future scenarios to determine the impacts of projected changes in climate and

528 LULC. For example, the fire season in the Okefenokee region is expected to extend two months

529 longer into the autumn by 2060 (Liu et al. 2013a), potentially increasing the intensity and thus

530 severity of fire. This kind of future scenario projection is a key contribution science partners

531 could provide to GOAL. Even if detailed assessments of future fire risk were to prove difficult to

532 project, scenario based planning could use an experimental approach to test the robustness of

533 management planning. For example, if fuel moisture were reduced by $10 \%$ across the fireshed,

534 would it be important to consider revisions or shifts in areas at high risk? 
536 Fire management in forests also will be challenged by increasingly fragmented landscapes with

537 shifting and novel species compositions.Given that Jacksonville, FL is a major port and the

538 center of urban development in the Okefenokee region, commercial transport and fragmentation

539 from development will likely facilitate the spread of invasive species (Wear 2013). The

540 expansion of invasive species will alter fuel dynamics and in turn, fire behavior. Climatic

541 envelope mapping can inform potential invasive species spread across regional scales for

542 inclusion in potential fuels mapping (Sheppard et al. 2014). Using this approach, Bradley et al

543 (2010) indicate ongoing range expansion of cogongrass (Imperata cylindrica), which is highly

544 flammable. Mapping potential scenarios of fuels will be a necessary part of fireshed risk

545 mapping. This mapping could include both continuous updating of invasive occurrence and

546 abundance from monitoring programs that might include a citizen science component, as well as

547 more technical species occurrence projections provided by scientific partners.

548

549 5.3. Achievable Future Conditions provide the foundation for prioritizing conservation and

550 management actions

551 In the context of fire management, current strategies that could be thought of as AFC-based

552 BMPs include "Fire-wise" community guidelines (www.firewise.org), which provide

553 recommendations for landowners to reduce impacts and spread of wildfires, such as using less

554 flammable landscaping and building materials (Stephens et al. 2013). Such programs historically

555 emphasized fire on a short term and case-by-case basis according to the landowner and 
556 community resources. Expanding BMPs to firesheds and incorporating preventative approaches

557 that account for future climate and land use change would broaden protection of human health,

558 safety, and economic interests across the Southeast while maintaining biodiversity in fire-

559 dependent communities (e.g. Gaither et al. 2011, Stanturf and Goodrick 2013, Mitchell et al.

560 2014).

561

562 In firesheds where the risk and potential costs of wildfire are increasing, BMPs could guide the

563 determination of acceptable levels of risk and effective management responses. Within such

564 risked-based approaches, high severity crown fire might be acceptable where human health and

565 safety are not jeopardized, such as across interior wilderness areas of Okefenokee NWR. This

566 approach is consistent with fireshed management, where severe wildfires are allowed to burn in

567 certain parts of the landscape to protect other areas of the landscape (e.g., North et al. 2012,

568 Stephens et al. 2013). Prioritizing areas of risk, including potential fire spread across the

569 landscape will require mapping not only future biophysical conditions (including drought stress

570 and fuel loads) but also social-economic conditions from future WUI and economically

571 vulnerable areas (e.g. Gaither et al. 2011). Establishing priorities will require technical guidance

572 from scientists in collaboration with land managers and owners. In high-risk areas of firesheds

573 such as WUI areas, recommended BMPs might include physical fire breaks (Agee et al. 2000) or

574 establishment of novel vegetation communities with lower fuel loads and flammability.

575 Recommendations might also mean that traditional Southeastern landscaping with flammable

576 materials, such as pine straw, will need to be reevaluated and/or moved away from structures. 
577 Landowners who wish to reduce the risk to timber investments might consider planting fire-

578 resistant and resilient species such as longleaf pine (Pinus palustris) in place of loblolly ( $P$.

579 taeda) or slash pine (P. elliotti) and designing pine plantations to minimize risks to developed

580 areas (Mitchell et al. 2014). These types of management approaches are unlikely to be perfectly

581 aligned with the interests of landowners--for example, fire breaks may only provide benefits to

582 adjacent areas--so they probably would not be adopted without some type of compensatory

583 exchange between landowners and beneficiaries, or policy intervention, most likely at the State

584 level.

585

586 Prescribed fire, along with wildland fire acceptance, or allowing wildfires in wilderness areas to

587 burn, will continue to be important BMPs for wildfire and biodiversity management in the

588 Southeast (Kirkman et al. 2001, Melvin 2012, Stanturf and Goodrick 2013, Mitchell et al. 2014).

589 Prescribed fire is often viewed as the most cost effective and ecologically beneficial fuels

590 management strategy (Melvin 2012). However, managers should expect that opportunities to use

591 fire would occur less frequently under future conditions, because of altered climate and concerns

592 about smoke management and air quality (Bhoi et al. 2009, Mitchell et al. 2014). Public

593 acceptance of prescribed fire will also be necessary and outreach from scientists and managers

594 can provide the public with information as a key part of the decision making process as to where

595 and when prescribed fire will be acceptable. Further, it will not be sufficient to reduce fire risk

596 on public land alone. Scientists and managers can provide private landowners with information

597 and technical support to implement prescribed burning. Already, states including Georgia and 
598 Florida provide assistance to landowners who seek it; however, states might need to move to a

599 more proactive recruitment process as wildfire risk increases.

600

601 Where prescribed fire is not feasible, implementation of firebreaks and/or conversion to less

602 flammable vegetation, particularly in the WUI, will be important BMPs to reduce future wildfire

603 risk across property boundaries. Even with aggressive management of fuels, many areas are

604 likely to experience high severity fires that may substantially alter ecosystem structure and

605 function. During the Georgia Bay Complex Fires, some recently prescribed burned $(<5$ years)

606 stands in the Osceola National Forest experienced high severity burns due to extremely dry

607 weather and high-risk fire conditions (Fire Behavior Assessment Team 2007). Further, GOAL

608 sought to create a wildfire buffer around the Okefenokee (goalpartners.org) following the 2007

609 fire season; so, the spread of the 2011 fires suggests that management will need adaptive and

610 increasingly aggressive approaches to contain fire under projected warmer and drier climatic

611 conditions (Stanturf and Goodrick 2013).

612

613 For the Okefenokee fireshed, determining acceptable levels of risk for management prioritization 614 will require coordination among state and federal agencies, GOAL, Prescribed Fire Councils, 615 and private landowners. Additional collaboration with climate and fire scientists will be required 616 to provide the technical information necessary to support informed risk assessment and decision

617 making. Risk assessment will most likely include multiple priorities and therefore tradeoffs

618 across the fireshed. Public agencies will likely prioritize risks to human health and safety, 
619 whereas private landowners might prioritize protecting high-value timber resources. Such

620 conflicting priorities could increase the overall fireshed risk. What is needed is an institutional

621 structure to incorporate scenario-based forecasts across ownership boundaries within firesheds,

622 to establish consensus-based goals for managing fire risk at a landscape scale, and regulatory or

623 compensatory mechanisms for facilitating private management activities that support broader

624 social benefits.

625

\section{6. Water Resources in the Flint River Basin}

627 Human population growth, urbanization, and climate change are increasing regional water

628 demands and depleting water sources in many areas of the Southeast (Sun et al. 2008, Carlisle et 629 al. 2011, Rugel et al. 2012, Famiglietti and Rodell 2013). The ability of water resources to meet

630 higher demand is limited, as the Southeast is characterized by small river basins, modest

631 groundwater resources, and relatively small, shallow storage reservoirs that are designed

632 primarily for flood control (Sun et al. 2013). In areas of high population growth such as the

633 Piedmont, which includes Atlanta GA, Charlotte NC, and Raleigh-Durham NC, regional heat-

634 island effects (e.g., www.epa.gov/heatisland/) formed by the combination of rapid

635 urban/suburban expansion and climate change may further stress water resources (Terando et al.

636 2014). Increased municipal water demands will affect aquatic biodiversity, as the development

637 of water resources is associated with a decrease in faunal richness and regional homogenization

638 of fauna (e.g., Moyle and Mount 2007).

639 
640 We use the Flint River in Georgia to illustrate how our risk-based conservation framework could

641 address water resource and aquatic biodiversity conservation concerns in the region. Draining

642 over two million ha, the Flint River watershed is approximately 50\% forested, $40 \%$ agriculture,

643 and 5\% urban. Hence, the region is a matrix of mixed land uses that interact in complex ways.

644 Originating in the metro Atlanta area, the Flint flows southward across the Piedmont and Coastal

645 Plain to its confluence with the Chattahoochee River, forming the Apalachicola River, which

646 flows from southwestern Georgia to the Florida panhandle. Water is withdrawn primarily for

647 power generation and municipal supply in the upper basin near Atlanta, and for agricultural

648 irrigation (e.g., row crops, pecan orchards) in the lower portions of the basin. Water use has

649 been expanding rapidly throughout the basin since the 1970's and growing season stream flows

650 are declining, particularly during droughts (Rugel et al. 2012, Emanuel and Rogers 2012).

651 During this period, there is no significant trend in annual or seasonal precipitation (Rugel et al.

652 2012, Emanuel and Rogers 2012). Between 2010 and 2050, the population of the upper basin is

653 expected to increase 63\%. In the lower Flint, water demand increased rapidly with the adoption

654 and expansion of crop irrigation during the 1970s and 80s (Couch et al. 1996). Total water use in

655 the Flint River Basin is projected to increase from 4.3 million $\mathrm{m}^{3}$ per day $\left(\mathrm{Mm}^{3} \mathrm{D}\right)$ in 2010 to 4.9

$656 \mathrm{Mm}^{3} \mathrm{D}$ in 2050 (Lower Flint Ochlockonee Watershed Council 2011, Upper Flint Watershed

657 Council 2011). With a future of increasing population, land use changes, temperatures, and

658 uncertain precipitation, water resource issues will become more critical. Allocation of water from

659 the Apalachicola-Chattahoochee-Flint River Basin has been a long-term source of contention

660 between Georgia, Florida and Alabama (see acfstakeholders.org). However, the development of 
661 water management guidelines for the Flint River, and many other southeastern rivers, is hindered

662 by the lack of systematic assessment of hydrologic change across mixed land uses. Particularly

663 lacking is information about changes in water yield or water balance in watersheds undergoing

664 development or land conversion (e.g., Sun et al 2008). Information concerning biological

665 responses, essential for developing water management guidelines, is also not well developed for

666 southeastern rivers. In the following sections, we explore the use of our conservation framework

667 to address water resource issues in the Flint basin (Figure 7).

668

669 6.1. Science-Management-Public partnerships as a foundation for conservation strategies

670 Stakeholder concerns about the availability of clean, fresh water in the Flint River basin led to

671 the formation of the Flint Riverkeeper (FRK) in 2008 (flintriverkeeper.org). Major stakeholders

672 within the basin include municipalities, agriculture, canoe liveries, and anglers. Concern arose

673 from an apparent increase in frequency and duration of droughts and an increase in the frequency

674 and duration of extreme low flows. Collectively, those observations suggested that the ability to

675 meet water demands, recreational needs, and support instream biota were increasingly uncertain

676 (Emanuel and Rogers 2012). There was also recognition that addressing water resource problems

677 in the Flint River required a broad integrative approach and coordinated efforts among diverse 678 stakeholder interests.

679

680 6.2. A risk-based approach to assess current conditions and develop conservation strategies in

681 the face of future uncertainty 
682 Future water resources and aquatic biodiversity depend on sustained streamflow, but this

683 requirement encompasses the magnitude, duration, frequency, timing, and rate of change in both

684 common and uncommon events (i.e., low flows, base flows, and flood pulses) (Olden and Poff

685 2003, Poff et al. 2010). Characterizing flow alteration is difficult because of the complex nature

686 of the hydrologic regimes and because information concerning biotic responses to altered stream

687 flows is site specific and/or often lacking. The Sustainable Boundary Approach (SBA) is a

688 method of stream flow assessment that simplifies data needs and reduces complexity. Using a

689 combination of stakeholder consensus, expert-opinion and evidence, an acceptable range of daily

690 stream flow is developed based on historical records (Richter 2009). This approach incorporates

691 societal values, technical expertise, along with flow augmentation and reduction, in water

692 management planning. The SBA approach has been further refined with the introduction of a

693 'presumptive standard' for environmental flow protection (Richter et al. 2011). Presumptive

694 standards are risk-based guidelines using case studies and real world experience with the SBA

695 template as a conceptual model.

696

697 We used the SBA and Presumptive Standard approach to assess hydrologic alteration and

698 develop AFCs for water resources in the Flint River (Richter et al. 2011). The main stem of the

699 Flint River has a number of US Geological Survey (USGS) gauging stations that provided data

700 (i.e., daily flow) for the SBA analysis. Based on demographic and land use data, we used 1975 as

701 a breakpoint for pre- and post-hydrologic alteration (e.g., Rugel et al. 2012, Emanuel and Rogers

702 2012); i.e., data from WY 1940-1974 were used to estimate 'pre-alteration' conditions, and data 
703 from 1975-2012 represented 'altered' flows. We calculated median average daily flow for each

704 day of the year, and upper and lower boundaries for SBA were calculated as the median daily

705 flow $\pm 20 \%$ (i.e., presumptive standard; Richter et al. 2011).

706

707 Median daily flow for the altered flow period shows substantial departure from the pre-alteration

708 period (Figure 8). From April through mid-October for WY 1974-2012, median daily flows are

709 often at or below the lower SBA boundary. Even during winter, when the WY 1974-2012 flow

710 generally resided within the SBA band, median daily flow seldom equaled or exceeded the pre-

711 alteration median value. This analysis suggests that substantial hydrologic alteration has already

712 occurred in the Flint River and is reflected in lower flows, particularly during late spring and

713 summer.

714

715 Under climate change scenarios, warmer temperatures along with variable rainfall, will result in

716 a continuing trend of hydrologic alteration. Human population growth would create additional

717 stress on water resources, exacerbating climate effects. Reduced summer stream flow and

718 increased stream temperature have negative implications for ecological communities in the river,

719 such as freshwater mussels (Golladay et al. 2004, Emanuel and Rogers 2012), native crayfish

720 (Sargent et al. 2011), and fish (van den Avyle and Evans 1990, Freeman et al. 2012, and

721 Emanuel and Rogers 2012). In addition to ecological effects, low flows would reduce the

722 seasonal volume of water available to receive permitted discharges. Increased discharge 
723 concentration, along with ecological changes may alter river assimilative capacity and increase

724 water treatment costs for downstream users.

725

726 The range of potential outcomes emerging from this analysis could be a starting point for

727 developing AFCs for the Flint River. This scenario building and risk assessment process would

728 provide an evaluation of whether costs (economic, social, and ecological) associated with

729 departures from the SBA are acceptable, followed by the development of achievable strategies

730 for addressing flow deficits. Sufficient technical information exists to guide management

731 responses and a monitoring network is in place to provide feedback. The challenge lies with

732 developing an institutional framework for engaging diverse social and economic interests in a

733 process leading to AFCs defined by environmental stream flows that could address tradeoffs

734 between ecological structure and function of the Flint River and the provision of various human

735 water uses. Key constituents include water utilities, industrial users, recreational users, and the

736 agricultural sector. The SBA approach is inherently adaptive, once goals for AFCs are set, data

737 collection and assessment can proceed and management activities adjusted based on river-

738 specific knowledge and economic/ecological interests.

739

740 6.3. Achievable Future Conditions provide the foundation for prioritizing conservation and

741 management actions

742 Concerns over future water resources motivate immediate consideration of strategies to address

743 vulnerabilities associated with extended periods of low flows in the Flint River. Increasing the 
744 availability of storage reservoirs is expensive and may be geologically challenging (Sun et al.

745 2013); therefore, efforts at reducing consumption might be emphasized over the short term. A

746 number of approaches have been suggested for the Flint River (e.g., Emanuel and Rogers 2012,

747 Emanuel 2014), such as better early recognition of drought conditions and faster responses in

748 reducing per capita water use in response to anticipated shortages. The Flint River is already part

749 of a National Oceanographic and Atmospheric Administration (NOAA) test program for regional

750 drought early warning efforts (http://www.drought.gov/drought/content/regional-programs).

751 Inclusion within this program indicates that monitoring capability is already in place, and water

752 utilities could use NOAA seasonal outlooks to more aggressively impose water conservation

753 measures before water storage reaches critical thresholds. Changing landscaping practices and

754 improving the efficiency of lawn irrigation systems can also reduce water demand during

755 seasonal dry periods. In municipal systems user demand approximately doubles during the

756 growing season, largely due to landscape watering (Emanuel and Rogers 2012). Another

757 approach is improving water distribution and use efficiency through repair of leaks in

758 distribution systems and incentives for improving end-user efficiencies. Several municipalities in

759 the upper Flint have initiated programs to improve efficiency of distribution and household water

760 use (e.g., Emanuel and Rogers 2012). With the exception of infrastructure repair and

761 improvement, many of the changes described above require water conservation encouraged

762 either through public information campaigns or with progressive water pricing mechanisms.

763 Longer term responses to potential water shortage could involve systematic examination of water

764 yield/balance at basin scales and adapting BMPs to enhance yields and reduce water loss. In 
765 urban areas, BMPs might include converting storm drain networks, which accelerate runoff, to

766 'green' infrastructure, which encourages water storage and infiltration (e.g. Jaffe 2011). In rural

767 areas of the lower Flint River basin, conversion of native forests to agriculture has accelerated

768 water stress by replacing water conservative vegetation with water demanding crops (Ford et al.

7692008 , S. Brantley unpublished data). Intensive agriculture also requires irrigation during periods

770 of low rainfall, putting additional seasonal stresses on water resources (Perry and Yager 2011).

771 In the lower Flint, improvements in agricultural irrigation efficiency are being adopted to reduce

772 seasonal demand (Perry and Yager 2011). However, there are limits to water savings that can be

773 acquired through improved efficiency. Under some futures, retirement of some agricultural lands

774 might provide the only feasible path to AFCs, suggesting some institutional structure to

775 compensate landowners for foregone revenue (similar perhaps to the Conservation Reserve

776 Program, but targeted to important components of this specific watershed).

777 At landscape scales, economically viable alternatives to water intensive irrigated agriculture need

778 to be developed and evaluated. Adoption could be encouraged through conservation easements

779 and incentives programs for reforestation. Programs have been initiated within the southeastern

780 US and include USDA Regional Conservation Partnership Programs (RCPP,

781 www.nrcs.usda.gov/wps/portal/nrcs/main/national/programs/farmbill/rcpp/) and the America's

782 Longleaf Restoration Initiative (ALRI, http://www.americaslongleaf.org/). While these programs

783 promote land conversion, their potential to affect regional water yield/balance and contribute to

784 restoration of river flows has not been assessed. This is a critical information need in developing

785 achievable future conditions for water resources in the southeastern US. 


\section{Summary and Conclusions}

789 In the context of using AFCs to guide conservation and management strategies, establishing

790 current conditions, developing scenarios for the future, and assessing risk is a largely technical

791 process; while determining AFCs is a collaborative social process between stakeholders and

792 technical experts. Technical information can provide insight into future biophysical envelopes;

793 however, stakeholder involvement is essential for determining social and policy goals. This

794 process emphasizes the need for strategies or forest management actions that are realistic given

795 ecological and social-economic constraints, have specific timelines for implementation, and have

796 measurable outcomes to evaluate success (e.g., Maxwell et al. 2015). Critical to this process is

797 developing a new suite of mitigative and adaptive BMP's that are applied at a regional scale.

798 Although uncertainty is inherent in projections of future climate and land use, there is abundant

799 evidence that rapid changes are altering forest ecosystem function and species distributions, and

800 some of these changes are irreversible, resulting in novel ecosystems. Management approaches

801 based solely on historic or current conditions are limited in their ability to sustain ecosystem

802 services critical to an expanding human population. Understanding of the ecological past and

803 current dynamics is necessary to establish baseline conditions, but not sufficient to guide

804 decision-making. Instead, these baselines must be applied in scenario-based forecasting to

805 generate a range of possible futures that can then be analyzed in a risk-based approach. These

806 futures should include a diversity of land uses. Strategies for management must be broadened, as 
807 public lands are not sufficient to sustain ecosystem services for society in regions dominated by

808 private land, such as the southeastern U.S. The notion of public versus private management

809 responsibility is particularly untenable for rivers, which cross large sections of landscape under a

810 variety of uses. Scientists, managers, policymakers, and stakeholder are therefore challenged to

811 collaborate across political boundaries and spatial and temporal scales. New approaches are

812 needed that anticipate and guide ecosystems in directions that mitigate undesirable outcomes.

813 This process will necessarily be adaptive as baseline conditions change, future scenario

814 projections are updated and societal needs shift with a growing and diversifying population. The

815 scientific community is tasked with advancing understanding of ecological dynamics and their

816 contribution to ecosystem services, improving simulation models, and communicating their

817 findings with managers and stakeholders. Together with scientists, managers will have to design

818 and implement monitoring programs that are crucial to appropriate management responses. The

819 critical need to provide an early warning of unexpected changes suggests that it will be

820 necessary to expand monitoring networks, including approaches such as citizen science

821 initiatives (Conrad and Hilchey 2011, Aceves-Bueno et al. 2015).

822

823 Our framework provides a starting point to move towards AFCs, illustrated with examples from

824 forest wildfire and water management in the southeastern U.S. It builds on work including the

825 forest management resistance- resilience- transition framework of Millar et al (2007), which

826 could be incorporated as part of the process to determine ACFs. It is also consistent with

827 environmental flows methodology, often proposed as an approach for developing water 
828 allocation strategies (Poff and Zimmerman 2010).We anticipate that points along the cycle will

829 be updated, and our framework will be adapted as information becomes available and dynamics

830 change. In an uncertain future of rapid change and abrupt, unforeseen transitions, adjustments in

831 management approaches will be necessary and some actions will fail. However, it is increasingly

832 evident that the greatest risk is posed by continuing to implement strategies inconsistent with and

833 not informed by current understanding of our novel future.

834

835

836

837 Many of the ideas presented in this paper developed from an Ichauway Conference held on

838 November 4-8, 2013 at the C.H. Kirbo Center of Bainbridge State College, Bainbridge GA. We

839 appreciate the presentations and stimulating contributions of all conference participants. S.

840 Hilliard and D. Rovig were integral in organizing conference logistics. N. Smith assisted with

841 final editing and manuscript preparation. We thank 2 anonymous reviewers whose comments

842 greatly improved a previous version of this paper. The idea of relating novel ecosystems to

843 resource management in the southeastern US originated with our late colleague Dr R.J. Mitchell,

844 we continue to appreciate his thoughtfulness. Funding was provided by the National Science

845 Foundation (EF-1243009), the USDA Forest Service, Southern Research Station, and the J.W.

846 Jones Ecological Research Center at Ichauway. 
850 Aceves-Bueno, E., Adeleye, A.S., Bradley, D., Brandt, W.T., Callery, P., Feraud, M., Garner, 851 K.L., Gentry, R., Huang, Y., McCullough, I., Pearlman, I., Sutherland, S.A., Wilkinson, W., 852 Yang, Y., Zink, T., Anderson, S.E., Tague, C., 2015. Citizen science as an approach for

853 overcoming insufficient monitoring and inadequate stakeholder buy-in in adaptive management:

854 Criteria and evidence. Ecosystems 18, 493-506.

855

Agee, J.L., Bahro, B., Finney, M.A., Omi, P.N., Sapsis, D.B., Skinner, C.N., van Wagtendonk, J.W., Weatherspoon, C.P., 2000. The use of shaded fuelbreaks in landscape fire management. Forest Ecol. and Manag. 127, 55-66.

Agrawal, A., Cashore, B., Hardin, R., Shepherd, G., Benson, C., Miller, D., 2013. Economic Contributions of Forests. Background Paper 1, United Nations Forum on Forests $10^{\text {th }}$ Session. Instanbul.

Ardón M., Morse, J., Colman, B., Bernhardt, E.S., 2013. Drought-induced saltwater incursion leads to increased wetland nitrogen export. Glob. Change Biol. 19, 2976-2985. doi:10.1111/gcb.12287.

Arvor, D., Durieux, L., Andres, S., LaPorte, M.-A., 2013. Advances in geographic object-based image analysis with ontologies: a review of main contributions and limitations from a remote sensing perspective. ISPRS J. Photogramm. 82, 125-137.

Aust, W.M., Blinn, C.R., 2004. Forestry best management practices for timber harvesting and site preparation in the eastern United States: and overview of water quality and productivity research during the past 20 years (1982-2002). Wat. Air. Soil Poll. Focus 4, 5-36.

Bagley, J.E., Desai, A.R., Harding, K.J., Snyder, P.K., Foley, J.A., 2014. Drought and deforestation: Has land cover change influenced recent precipitation extremes in the Amazon? J. Climate 27, doi 10.1175/JCLI-D-12-00369.1

Bahro, B., Barber, K.H., Sherlock, J.W., Yasuda, D.A., 2007. Stewardship and fireshed assessment: a process for designing a landscape fuel treatment strategy. USDA Forest Service GTR PSW-203.

Benke, A.C., 1990. A perspective on America's vanishing streams. J. North Amer. Benthol. Soc. 9, 77-88.

Bhoi, S., Qu, J. J., Dasgupta, S., 2009. Multi-sensor study of aerosols from 2007 
Okefenokee forest fire. J. Appl. Remote Sens. 3(031501) doi, 10.1117/1.3078070.

Bradley, B.A., Wilcove, D.S., Oppenheimer, M., 2010. Climate change increases risk of plant invasion in the Eastern United States. Biol. Invasions 12, 1855-1872.

Burr, B.M., Mayden, R.L., 1992. Phylogenetics and North American freshwater fishes, in:

895

896

Mayden, R.W., (Ed.), Systematics, Historical Eco
Stanford University Press, Stanford, pp. 18-75.

Butler, B.J., Wear, D.N., 2013. Forest Ownership dynamics of Southern forests, in: Wear, D.N., Greis, J.G., (Eds.), The Southern Forest Futures Project, USDA Forest Service, GTR SRS-178, Ashville, pp. 103-122.

Caldwell, P., Muldoon, C., Ford-Miniat, C., Cohen, E., Krieger, S., Sun, G., McNulty, S., Bolstad, P.V., 2014. Quantifying the role of National Forest System lands in providing surface drinking water supply for the Southern United States. USDA Forest Service, GTR SRS-197, Asheville.

Carlisle, D.M., Wolock, D.M., Meador, M.R, 2011. Alteration of streamflow magnitudes and potential ecological consequences: a multiregional assessment. Front. Ecol. Environ. 9, 264-270.

Carpenter, S.R., Folke, C., Scheffer, M., Westley, F., 2009. Resilience: Accounting for the noncomputable. Ecol. Soc.14, 13 (www.ecologyandsociety.org/vol14/iss1/art13/).

Chapin, III., F.S., Folke, C., Kofinas G.P., 2009. A framework for understanding change, in: Chapin, F.S., (Ed.), Principles of Ecosystem Stewardship, DOI 10.1007/978-0-387-73033-2, Springer-Verlag, New York, pp. 3-28.

Christensen, N.L., Bartuska, A.M., Brown, J.H., Carpenter, S., D’Antonio, C., Francis, R., Franklin, J.F., MacMahon, J.A., Noss, R.F., Parsons, D.J., Peterson, C.H., Turner, M.G., Woodmansee, R.G., 1996. The report of the Ecological Society of America Committee on the Scientific Basis for Ecosystem Management, Ecol. Appl. 6, 665-691, dx.doi.org/10.2307/2269460.

Conrad, C.C., Hilchey, K.G., 2011. A review of citizen science and community-based environmental monitoring: issues and opportunities. Environ. Monit. Assess. 176, 273-291.

Couch, C.A., Hopkins, E.H., Hardy, P.S., 1996. Influences of environmental settings on aquatic ecosystems in the Apalachicola-Chattahoochee-Flint River basin. USGS Water-Resources Investigations Report 95-4278, Reston. 
Dale, V.H., Brown, S., Haeuber, R., Hobbs, N.T., Huntley, N., Naiman, R.J., Riebsame, W.E.,

930 Turner, M.G., Valone, T., 2000. Ecological principles and guidelines for managing the use of

931 land. Ecol. Appl. 10, 639-670.

932

933

934

935

936

937

938

939

940

941

942

943

944

945

946

947

948

949

950

951

952

953

954

955

956

957

958

959

960

961

962

963

964

965

966

967

968

Dickinson, J. L., Shirk, J.L., Bonter, D.N., Bonney, R.E., Crain, R.L., Martin, J., Phillips, T., Purcell, K.A., 2012. The current state of citizen science as a tool for ecological research and public engagement. Front. Ecol. Environ.10, 291-297.

Edwards, L., Ambrose, J., Kirkman, L.K., 2013. The Natural Communities of Georgia. University of Georgia Press. Athens.

Emanuel, B., Rogers,G., 2012. Running dry: Challenges and opportunities in restoring healthy flows in Georgia's upper Flint River Basin. American Rivers.

www.AmericanRivers.org/RunningDry. Atlanta.

Famiglietti, J.S., Cazenave, A., Eiker, A., Reager, J.T., Rodell, M., Velicogna, I., 2015. Satellites provide the big picture. Science 349: 684-685.

Famiglietti, J.S., Rodell, M., 2013. Water in the balance. Science 340, 1300-1301.

Fekete, B.M., Robarts, R.D., Kumagai, M., Nachtnebel, H.-P., Odada, E., Zhulidov, A.V., 2015. Time for in situ renaissance. Science 349: 685-686.

FAO and JRC, 2012. Global forest land-use change 1990-2005, in: Lindquist, E.J., D'Annunzio, R., Gerrand, A., MacDicken, K., Achard, F., Beuchle, R., Brink, A., Eva, H.D., Mayaux, P., SanMiguel-Ayanz J., Stibig, H-J., (Eds.), FAO Forestry Paper No. 169, Food and Agriculture

Organization of the United Nations and European Commission Joint Research Centre, Rome.

Ford, C.R., Mitchell, R.J., Teskey, R.O., 2008. Water table depth affects productivity, water use, and the response to nitrogen addition in a savanna system. Can. J. Forest Res. 38, 2218-2127.

Freeman, M.C., Buell, G.R., Hay, L.E., Hughes, W.B., Jacobson, R.B., Jones, J.W., Jones, S.A., LaFontaine, J.H., Odum, K.R., Peterson, J.T., Riley, J.W., Schlinder, J.S., Shea, C., Weaver, J.D., 2012. Linking river management to species conservation using dynamic landscape-scale models. River Res. Appl. DOI, 10.1002/rra.2575.

Gaither, C.J., Poudyal, N.C., Goodrick, S., Bowker, J.M., Malone S., Gan, J., 2011. Wildland fire risk and social vulnerability in the Southeastern United States: An exploratory spatial data analysis approach. Forest Policy Econ. 13, 24-36. 
Golladay, S.W., Gagnon, P., Kearns, M., Battle, J.M., Hicks, D.W., 2004. Response of freshwater mussel assemblages (Bivalvia: Unionidae) to a record drought in the Gulf Coastal

Gunderson, L.H., 2000. Ecological resilience - In theory and application. Annu. Rev. Ecol. Syst. 31, 425-439.

Haddad, N.M., Brudvig, L.A., Clobert, J., Davies, K.F., Gonzalez, A., Holt, R.D., Lovejoy, T.E., Sexton, J.O., Austin, M.P., Collins, C.D., Cook, W.M., Damschen, E.I., Ewers, R.M., Foster, B.L., Jenkins, C.N., King, A.J., Laurance, W.F., Levey, D.J., Margules, C.R., Melbourne, B.A., Nicholls, A.O., Orrock, J.L., Song, D.-A., Townshend, J.R.. 2015. Habitat fragmentation and its lasting impact on Earth's ecosystems. Science Adv. 2015;1:e1500052.

Hargrove, W.H., Spruce, J.P., Gasser, G.E., Hoffman, F.M., 2009. Toward a national early warning system for forest disturbances using remotely sensed canopy phenology. Photogramm. Eng. Rem. S. 75, 1150-1156.

Hobbs, R.J., Higgs, E., Hall, C.M., Bridgewater, P.M., Chapin, III, F.S., Ellis, E.C., Ewel, J.J., Hallett, L.M., Harris, J., Hulvey, K.B., Jackson, S.T., Kennedy, P.L., Kueffer, C., Lach, L., Lantz, T.C., Lugo, A.E., Mascaro, J., Murphy, S.D., Nelson, C.R., Perring, M.P., Richardson, D.M., Seastedt, T.R., Standish, R.J., Starzomski, B.M., Suding, K.N., Tognetti, P.M., Yakob, L., Yung, L., 2014. Managing the whole landscape: Historical, hybrid, and novel ecosystems. Front. Ecol. Environ. 12, 557-564.

Hobbs, R.J., Higgs, E.S., Hall, C.M., 2013. Novel ecosystems: Intervening in the new ecological world order. John Wiley \& Sons, Ltd, Chichester.

Hobbs, R.J., Higgs, E., Harris, J.A., 2009. Novel ecosystems: implications for conservation and restoration. Trends Ecol. Evol. 24, 599-605.

Hobbs, R.J., Arico, S., Aronson, J., Baron, J.S., Bridgewater, P., Cramer, V.A., Epstein, P.R., Ewel, J.J., Klink, C.A., Lugo, A.E., Norton, D., Ojima, D., Richardson, D.M., Sanderson, E.W., Valladares, F., Vila, M., Zamora, R., Zobel, M. 2006. Novel ecosystems: theoretical and management aspects of the new ecological world order. Global Ecol. Biogeogr. 15, 1-7.

IPCC, 2007. Climate Change 2007: Synthesis Report, in: Core Writing Team, Pachauri, R.K and Reisinger, A. (Eds), Contribution of Working Groups I, II and III to the Fourth Assessment Report of the Intergovernmental Panel on Climate Change, Geneva.

IPCC, 2014. Climate Change 2014: Synthesis Report, in: Core Writing Team, Pachauri, R.K., Meyer, L.A. (Eds.), Contribution of Working Groups I, II and III to the Fifth Assessment Report of the Intergovernmental Panel on Climate Change, Geneva. 
1012

1013

1014

1015

1016

1017

1018

1019

1020

1021

1022

1023

1024

1025

1026

1027

1028

1029

1030

1031

1032

1033

1034

1035

1036

1037

1038

1039

1040

1041

1042

1043

1044

1045

1046

1047

1048

1049

1050

1051

1052
Iverson, L R., Matthews, S.N., Prasad, A.M., Peters, M.P., Yohe. G., 2012. Development of risk matrices for evaluating climatic change responses of forested habitats. Climatic Change 114, 231-243.

Jaffe, M., 2011. Reflections on green infrastructure economics. Environ. Practice 12, 357-365.

Kao, R.H., Gibson, C.M., Gallery, R.E., Meier, C.L., Barnett, D.T., Docherty, K.M., Blevins, K.K., Travers, P.D., Azuaje, E., Springer, Y.P., Thibault, K.M., McKenzie, V.J., Keller, M., Alves, L.F., Hinckley, E.S., Parnell, J., Schimel D., 2012. NEON terrestrial field observations: designing continental-scale, standardized sampling. Ecosphere 3, dx.doi.org/10.1890/ES1200196.1

Kerr, J.T., Ostrovsky, M., 2003. From space to species: Ecological applications for remote sensing. Trends Ecol. Evol. 18, 299-305.

Kirkman, L.K, Mitchell, R.J., Helton, R.C., Drew, M.B., 2001. Productivity and species richness across an environmental gradient in a fire-dependent ecosystem. Amer. J. Bot. 88, 2119-2128.

Klepzig, K., Shelfer R., Choice, Z., 2014. Outlook for coastal plain forests: A subregional report from the Southern Forest Futures Project. USDA Forest Service, GTR SRS-GTR-196. Ashville.

Likens, G., 2001. Biogeochemistry, the watershed approach: Some uses and limitations. Mar. Freshwat. Res. 52, 5-12.

Lindenmayer, D., Likens, G., 2010. The science and application of ecological monitoring. Biol. Conserv. 143, 1317-1328.

Liu, Y.Q., Goodrick, S.L., Stanturf,J.A., 2013a. Future U.S. wildfire potential trends projected using a dynamically downscaled climate change scenario. Forest Ecol. Manag. 294, 120-135.

Liu, Y.Q., Prestemon, J., Goodrick, S.L., Holmes, T.P., Stanturf, J.A., Vose, J.M., Sun, G., 2013b. Future wildfire trends, impacts and mitigation options in the Southern United States, in Vose, J.M., Klepzig, K., (Eds.), Climate Change Adaptation and Mitigation Management Options. CRC Press, Boca Raton, pp. 85-126.

Lockaby, G., Nagy, C., Vose, J. M., Ford, C. R., Sun, G., McNulty, S., Caldwell, P., Cohen, E., Moore Myers, J., 2013. Forests and Water, in: Wear, D.N., Greis, J.G., (Eds.), The Southern Forest Futures Project: Technical Report. USDA Forest Service GTR SRS-178, Asheville, pp. 309-339. 
1053

1054

1055

1056

1057

1058

1059

1060

1061

1062

1063

1064

1065

1066

1067

1068

1069

1070

1071

1072

1073

1074

1075

1076

1077

1078

1079

1080

1081

1082

1083

1084

1085

1086

1087

1088

1089

1090

1091

1092

1093
Lower Flint-Ochlockonee Regional Water Plan. 2011.

www.flintochlockonee.org/documents/LFO_Adopted_RWP.pdf. (Accessed September 2015).

Maes, J., Egoh, B., Willemen, L., Liquete, C., Vihervaara, P., Schager, J.P., Grizzetti, B., Drakou, E.V., La Notte, A., Zulian, G., Bouraoui, F., Paracchini, M.L., Bratt, L., Bidoglio, G., 2012. Mapping ecosystem services for policy support and decision making in the European Union. Ecosyst. Serv. 1, 31-39.

Maxwell, S.L., Milner-Gulland, E.J., Jones, J.P.G., Knight, A.T., Bunnefeld, N., Nuno, A., Bal, P., Earle, S., Waterson, J.E.M., Rhodes, J.R., 2015. Being smart about SMART environmental targets. Science 347, 1075-1076.

McDowell, W.H., 2015. NEON and STREON: opportunities and challenges for the aquatic sciences. Freshwat. Sci. 34, 386-391.

McNulty, S., Myers, J.M., Caldwell P., Sun, G., 2013. Climate change summary, in: Wear, D.N., Greis, J.G., (Eds.), The Southern Forest Futures Project. USDA Forest Service GTR SRS-178. Ashville, pp. 27-44.

Melillo, J. M., Richmond, T., Yohe, G.W., 2014. Climate Change Impacts in the United States: The Third National Climate Assessment. U.S. Global Change Research Program, doi:10.7930/J0Z31WJ2.

Melvin, M., 2012. National prescribed fire use survey report. Coalition of Prescribed Fire Councils Technical Report 01-12, Newton.

Mercer, D.E., Cooley, D., Hamilton, K., 2011. Taking stock: Payments for forest ecosystem services in the United States. Forest Trends Association. Washington, DC.

Millar, C.I., Stephenson, N.L., Stephens, S.L., 2007. Climate change and forests of the future: Managing in the face of uncertainty. Ecol. Appl. 17, 2145-2151.

Milly, P.C.D., Betancourt, J., Falkenmark, M., 2008. Climate change: Stationarity is dead: Whither water management? Science 319, 573 - 574.

Mitchell, R.J., Youngqiang, L., O’Brien, J.J., Elliott, K.J., Starr, G., Miniat, C.F., Hiers, J.K., 2014. Future climate and fire interactions in the southeastern region of the United States. Forest Ecol. Manag. 327, 316-326.

Moyle, P.B., Mount, J.F., 2007. Homogenous rivers, homogenous faunas. Proc. Nat. Acad. Sci. USA 104, 5711-5712. 
1094 Naiman, R.J., 2013. Socio-ecological complexity and the restoration of river ecosystems. Inland 1095 Waters 3, 391-410.

1096

1097

1098

1099

1100

1101

1102

1103

1104

1105

1106

1107

1108

1109

1110

1111

1112

1113

1114

1115

1116

1117

1118

1119

1120

1121

1122

1123

1124

1125

1126

1127

1128

1129

1130

1131

1132

1133
Neves, R.J., Bogan, A.E., Williams, J.D., Ahlstedt, S.A., Hartfield, P.W., 1997. Status of aquatic mollusks in the southeastern United States: a downward spiral of diversity, in: Benz, G. W. Collins, D. E., (Eds.), Aquatic Fauna in Peril: The Southeastern Perspective. Southeastern Aquatic Research Institute, Lenz Design and Communications, Decatur, pp. 43-85.

North. M., Collins, B.M., Stephens, S., 2012. Using fire to increase the scale, benefits, and future maintenance of fuels treatments. J. Forest. 110, 392-401.

Odman, T., Hu, Y., Russel, A., 2007. Forecasting the Impacts of Wildfires. 2007 CMAQ User Workshop, Chapel Hill, www.cmascenter.org .

Ojima, D.S., Iverson, L.R., Sohngen. B.L., 2012. Appendix 2: Risk-based framework and risk case studies: Risk-based framework for evaluating changes in response thresholds and vulnerabilities, in: Vose, J.M., Peterson, D.L., Patel-Weynand, T., (Eds), Effects of Climatic Variability and Change on Forest Ecosystems: A Comprehensive Science Synthesis for the U.S. Forest Sector. USDA Forest Service, GTR PNW-GTR-870. Portland, pp. 243-245.

Ojima, D.S., L.R. Iverson, B.L. Sohngen, J.M. Vose, C.W.Woodall, G.M. Domke, D.L. Peterson, J.S. Littell, S.N. Matthews, A.M. Prasad, M.P. Peters, G.W. Yohe, and M.M. Friggens. 2014. Risk Assessment. Pages 223-244 in Petersen, D.L., J.L. Vose, and T. Patel-Weyland, editors. Climate Change and United States Forests. Advances in Global Change Research 57, DOI 10.1007/978-94-007-7515-2_9.

Olden, J.D., Poff, N.L., 2003. Redundancy and the choice of hydrologic indices for characterizing streamflow regimes. Riv. Res. Appl. 19, 101-121.

Perry, C., Yager, R., 2011. Irrigation water conservation efforts at the UGA C.M. Stripling Irrigation Research Park. Proceedings of the 2011 Georgia Water Resources Conference. Athens.

Pettorelli, N., Vik, J.O., Mysterud, A., Gaillard, J-.M., Tucker, C.J., Stenseth, N.C., 2005. Using satellite-derived NDVI to assess ecological responses to environmental change. Trends Ecol. Evol. 20, 503-510.

Pickett, S.T.A., Parker, V.T., Fiedler, P. L., 1992. The new paradigm in ecology: implications for conservation biology above the species level, in: Fiedler P.L., Jain, S.K., (Eds.), Conservation Biology: The Theory and Practice of Nature Conservation, Preservation, and Management, Chapman and Hall, New York, pp. 65-88. 
1134 Poff, N.L., Richter, B.D., Arthington, A.H., Bunn, S.E., Naiman, R.J., Kendy, E., Acreman, M., 1135 Apse, C., Bledsoe, B.P., Freeman, M.C., Henriksen, J., Jacobson, R.B., Kennen, J.G., Merritt, 1136 D.M., O'Keefe, J.H., Olden, J.D., Rogers, K., Tharme, R.E., Warner, A., 2010. The ecological limits of hydrologic alteration (ELOHA): A new framework for developing regional environmental flow standards. Freshwat. Biol. 55, 147-170.

Poff, N.L., Zimmerman, J.K.H., 2010. Ecological responses to altered flow regimes: A literature review to inform the science and management of environmental flows. Freshwat. Biol. 55, 194205.

Prato, T. 2008. Accounting for risk and uncertainty in determining preferred strategies for adapting to future climate change. Mitig. Adapt. Strateg. Glob. Change 13, 47-60.

Prud'homme, B.A., Greis, J.G., 2002. Best management practices in the south, Chapter 22, in: Wear, D.N., Greis, J.G., (Eds.), The Southern Forest Resource Assessment: Technical Report. USDA Forest Service, GTR SRS-53, Ashville, pp. 519-535.

Radeloff, V.C., Hammer, R.B., Stewart, S.I., Fried, J.S., Holcomb, S.S., McKeefry, J.F., 2005. The wildland-urban interface in the United States. Ecol. Appl. 15, 799-805.

Reager, J.T., Thomas, B.F., Famiglietti, J.S., 2014. River basin flooding potential inferred using GRACE gravity observations at several months lead time. Nat. Geosc. 7, 588-592.

Reed, M.S., Graves, A., Dandy, N., Posthumus, H., Hubacek, K., Morris, J., Prell, C., Quinn, C.H., Stringer, L.C., 2009. Who's in and why? A topology of stakeholder analysis methods for natural resource management. J. Environ. Manag. 90, 1933-1949.

Rieman, B.E., Smith, C.L., Naiman, R.J., Ruggerone, G., Wood, C.C., Huntly, N., Merrill, E.N., Alldredge, J.R., Bisson, P.A., Congleton, J., Fausch, K., Levings, C., Pearcy, W., Scarnecchia, D., Smouse, P., 2015. A comprehensive approach for habitat restoration in the Columbia Basin. Fisheries 40, 124-135. sustainability boundaries. Riv. Res. Appl. DOI, 10.1002/rra.1320.

Richter, B.D., Davis, M.M., Apse, C., Konrad, C., 2011. A presumptive standard for environmental flow protection. Riv. Res. Appl. DOI, 10.1002/rra.1511. 
1175 Sargent, L.W., Golladay, S.W., Covich, A.P., Opsahl, S.P., 2011. Physicochemical habitat association of a native and non-native crayfish in the lower Flint river, Georgia: Implications for invasion success. Biol. Invasions 13, 499-511.

Schimel, D., Keller, M., 2015. Big questions, big science: meeting the challenges of global ecology. Oecol., DOI 10.1007/s00442-015-3236-3.

Seastedt, T.R., Hobbs, R.J., Suding, K.N., 2008. Management of novel ecosystems: Are novel approaches required? Front. Ecol. Environ. 6, 547-553.

Sheppard, C.S., Burns, B., Stanley, M.C., 2014. Predicting plant invasions under climate change: are species distribution models validated by field trials? Glob. Change Biol. 20, 2800-2814.

Shortle, J.S., Horan, R.D., 2013. Policy instruments for water quality protection. Annu. Rev. Resour. Econ. 5, 111-138.

Stanturf, J.A. and Goodrick, S.L., 2013. Fire, in: Wear D.N., Greis, J.G., (Eds),. The Southern Forest Futures Project. USDA Forest Service GTR SRS-178. Ashville, pp. 509-529

Steffen, W., Crutzen, P.J., McNeill, J.R., 2007. The Anthropocene: Are humans now overwhelming the great forces of nature. Ambio 36, 614-621,

Stephens, S.L., Agee, J.K., Fule, P.Z., North, M.P., Romme, W.H.,. Swetnam, T.W., Turner, M.G., 2013. Managing forests and fire in changing climates. Science 342, 41-42.

Sun, G., McNulty, S.G., Moore, J.A., Cohen, E.C., 2008. Impacts of multiple stresses on water demand and supply across the southeastern United States. J. Amer. Water Resour. Assoc. 44, 1441-1457.

Sun, G., Caldwell, P.V., McNulty, S.G., Georgakakos, A.P., Arumugam, S., Cruise, J., McNider, R.T., Terando, A., Conrads, P.A., Feldt, J., Misra, V., Romolo, L., Rasmussen, T.C., Marion, D.A. 2013. Impacts of Climate Change and Variability on Water Resources in the Southeast USA. USDA Forest Service, NCA Southeast Technical Report 204-234. Ashville.

Terando, A.J., Costanza, J., Belyea, C., Dunn, R.R., McKerrow, A., Collazo, J.A., 2014. The southern megalopolis: Using the past to predict the future of urban sprawl in the southeast U.S. PLOSone 9, e102261. doi:10.1371/journal.pone.0102261. deficit approach for hydrological drought characterization. Geoph. Res. Lett. 41,1537-1545. 
Upper Flint Regional Water Plan. 2011. www.upperflint.org/documents/UFL_Adopted_RWP.pdf. (Accessed September 2015).

van den Avyle, M.J., Evans, J.W., 1990. Temperature selection by Striped Bass in a Gulf of

Wear, D.N., Greis, J.G. 2013. The Southern Forest Futures Project: Technical Report, USDA Forest Service, GTR SRS-178, Ashville.

Wear, D.N. 2013. Forecasts of land uses, in: Wear, D.N., Greis, J.G., (Eds.), The Southern Forest Futures Project. USDA Forest Service, GTR SRS-178, Ashville, pp. 45-72.

Westgate, M.J., Likens, G.E., Lindenmayer, D.B., 2013. Adaptive management of biological systems: a review. Biol. Conserv. 158, 128-139.

Woodall, C.W., Amacher, M.C., Bechtold, W.A., Coulston, J.W., Jovan, S., Perry, C.H., Randolph, K.C., Schulz, B.K., Smith, G.C., Tkacz, B., Will-Wolf, S., 2011. Status and future of the forest health indicators program of the USA. Environ. Monit. Assess. 177, 419-436.

Yin, Z. 1993. Fire regime of the Okefenokee Swamp and its relation to hydrological and climatic conditions. Int. J. Wildland Fire 3, 229-240.

Yohe, G.,Leichenko, R., 2010. Adopting a risk-based approach. Ann. NY.

Acad. Sci., Special Issue on the New York City Panel on Climate Change, 196, 29-40.

Zhang, R., Delworth, T.L., Sutton, R., Hodson, D.L.R., Dixon, K.W., Held, I.M., Kushnir, Y., Marshall, J., Ming, Y., Msadek, R., Robson, J., Rosati, A.J., Ting, M.-F., Vecchi, G.A., 2013. Have aerosols caused the observed Atlantic multidecadal variability? J. Atmos. Sci. 70, 11351144 .

Zhang, Y., He, H.S., Yang, J., 2008. The wildland-urban interface dynamics in the southeast U.S. from 1990 to 2000. Landscape and Urban Plan. 85, 155-162. 
1254 Table 1. Organizations currently working at landscape scale management coordination in the 1255 Southeast. These organizations can be key players in any new efforts in conservation management; however, a key distinction between existing efforts and the proposed framework is the focus on scenario-based planning, risk assessment, and landscape monitoring.

$\begin{array}{lllll}\text { Organization } & \bullet & \text { Description } & \bullet \text { Public-private } & \begin{array}{l}\text { Scenario-based future } \\ \text { planning, risk }\end{array} \\ & \bullet & \text { Goal } & \text { partnerships } & \begin{array}{l}\text { assessment, or landscape } \\ \text { monitoring? }\end{array}\end{array}$

\begin{tabular}{|c|c|c|c|}
\hline $\begin{array}{l}\text { Landscape } \\
\text { Conservation } \\
\text { Cooperatives } \\
\text { (LCCs) }\end{array}$ & $\begin{array}{l}\text { Collaboration among FWS, } \\
\text { USGS, state agencies. } \\
\text { Support integrated landscape } \\
\text { conservation. } \\
\text { Spatially explicit Conservation } \\
\text { Blueprint }\end{array}$ & $\begin{array}{ll}- & \text { Yes } \\
- & \text { Primarily focused } \\
& \text { on public land }\end{array}$ & $\begin{array}{l}\text { - Capacity to update } \\
\text { conservation blueprint }\end{array}$ \\
\hline $\begin{array}{l}\text { Coalition of } \\
\text { Prescribed Fire } \\
\text { Councils }\end{array}$ & $\begin{array}{l}\text { Promotes prescribed fire } \\
\text { management, supports } \\
\text { landowners. }\end{array}$ & $\begin{array}{ll}\text { - } & \text { Yes- } \\
\text { - } & \text { Primarily focused } \\
& \text { on private land }\end{array}$ & - $\quad$ No \\
\hline $\begin{array}{l}\text { America's } \\
\text { Longleaf } \\
\text { Initiative }\end{array}$ & $\begin{array}{l}\text { Federal, state and private industry } \\
\text { collaboration across nine } \\
\text { Southeastern states with } \\
\text { Goal to more than double the area } \\
\text { of longleaf pine in } 15 \text { years }\end{array}$ & $\begin{array}{ll}\text { - } & \text { Yes } \\
\text { - } & \text { Focused across } \\
\text { ownerships }\end{array}$ & $\begin{array}{l}\text { - Local implementation } \\
\text { teams }\end{array}$ \\
\hline $\begin{array}{l}\text { Greater } \\
\text { Okefenokee } \\
\text { Association of } \\
\text { Landowners } \\
\text { (GOAL }\end{array}$ & $\begin{array}{l}\text { Federal, state and private industry } \\
\text { landowners in the Okefenokee } \\
\text { region of GA, FL } \\
\text { Goal to respond to wildfire and } \\
\text { reduce risk. }\end{array}$ & - $\quad$ Yes & - $\quad$ No \\
\hline $\begin{array}{l}\text { Flint } \\
\text { Riverkeeper }\end{array}$ & $\begin{array}{l}\text { - Stakeholder NGO } \\
\text { Goal to "restore and preserve the } \\
\text { habitat, water quality and flow of } \\
\text { the Flint River for the benefit of } \\
\text { current and future generations and } \\
\text { dependent wildlife" }\end{array}$ & - $\quad$ Yes & - $\quad \mathrm{No}$ \\
\hline $\begin{array}{l}\text { ACF } \\
\text { Stakeholders }\end{array}$ & $\begin{array}{l}\text { - } \quad \text { Stakeholder NGO } \\
\text { Goal to "achieve equitable water- } \\
\text { sharing solutions among } \\
\text { stakeholders that balance } \\
\text { economic, ecological and social } \\
\text { values, while ensuring } \\
\text { sustainability for current and } \\
\text { future generations" }\end{array}$ & - Yes & - No \\
\hline
\end{tabular}




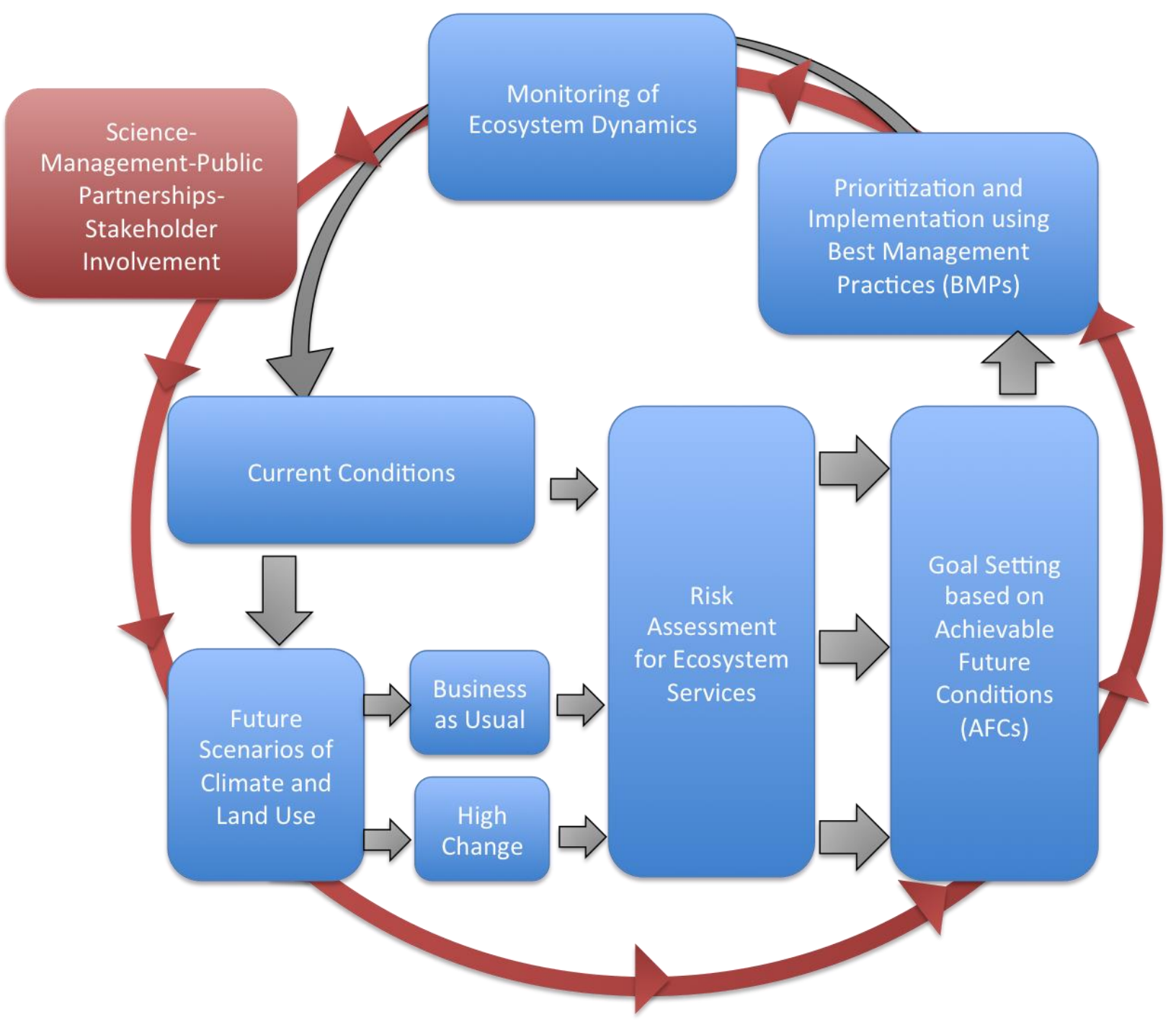

Figure 1. Framework for conservation management for achievable future conditions, based on scenario and risk assessments. The red line and arrows show that stakeholder engagement is a continuous process, with an expectation of frequent engagement at all stages of conservation management. 

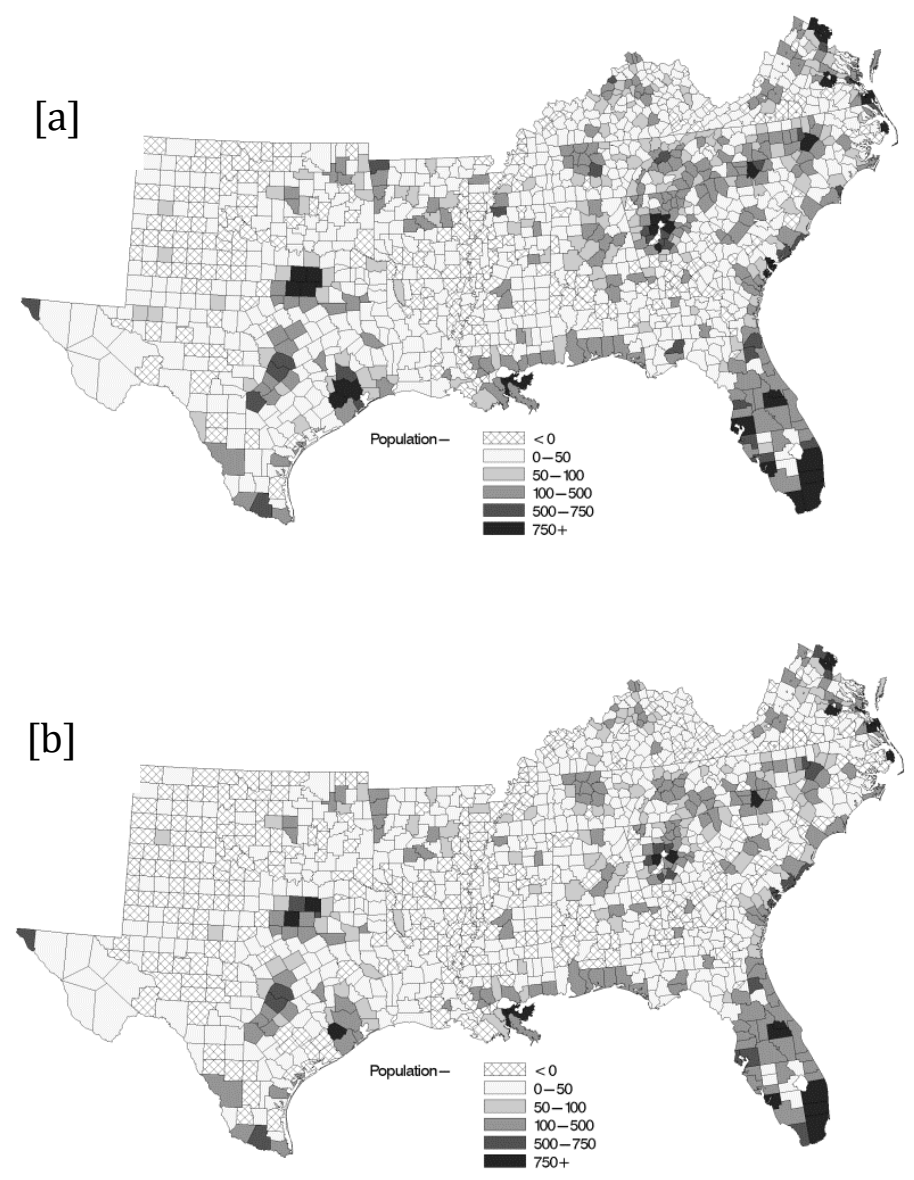

Figure 2. Projection of population change in the Southeastern United States, 2010-2060, assuming the (a) A1B storyline of low population growth, high economic growth, high-energy use; and (b) B2 storyline of moderate growth and energy use from the 2010 Resources Planning Act (RPA) assessment. Note that counties in crosshatch have forecasted population losses. Adapted from Wear and Greis (2013). 
[a]

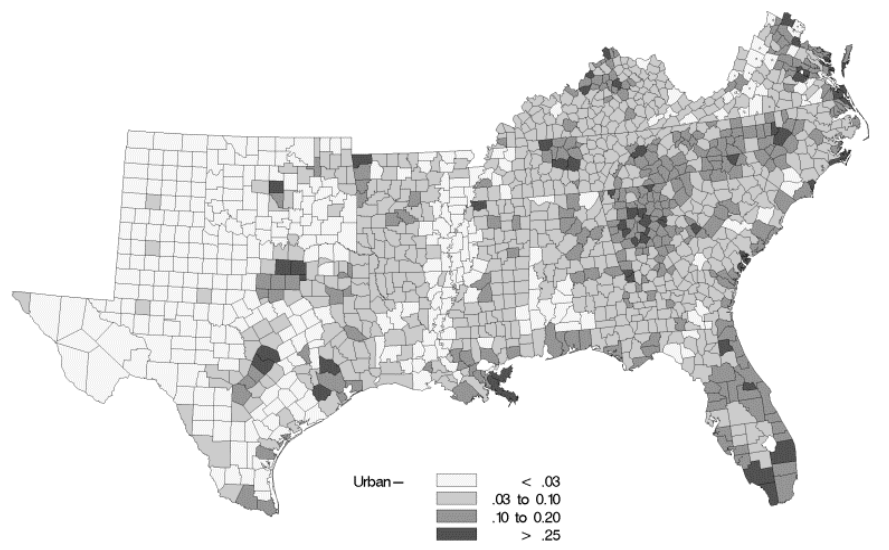

1306

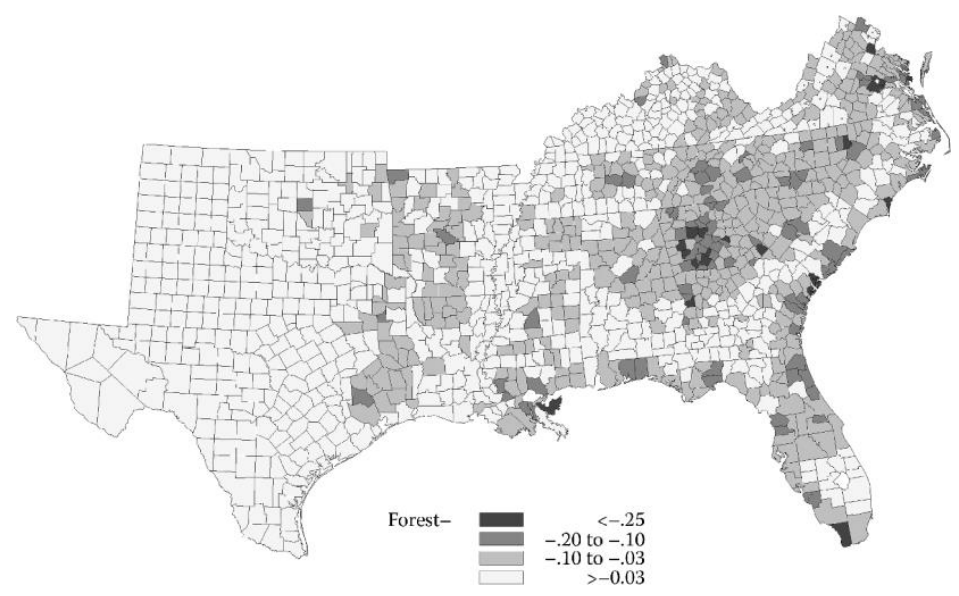

1319 Figure 3. Proportional change in land 1997- 2060, a. Percent change (increase) in urban land use. 

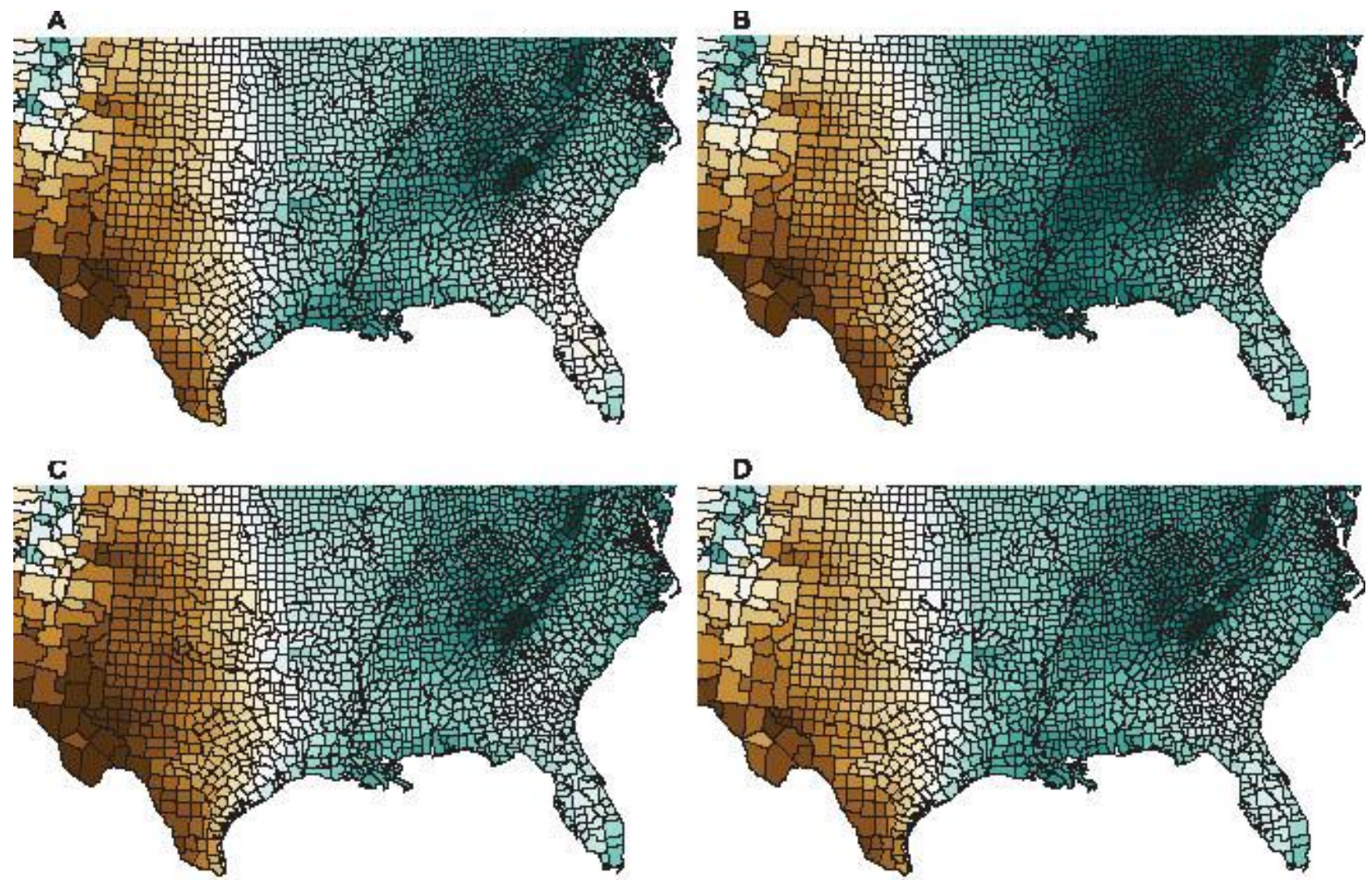

1325

1326

1327 Figure 4. Comparison of annual fire potential for future conditions (2060). Adapted from 1328 Stanturf and Goodrick (2013).

1329 


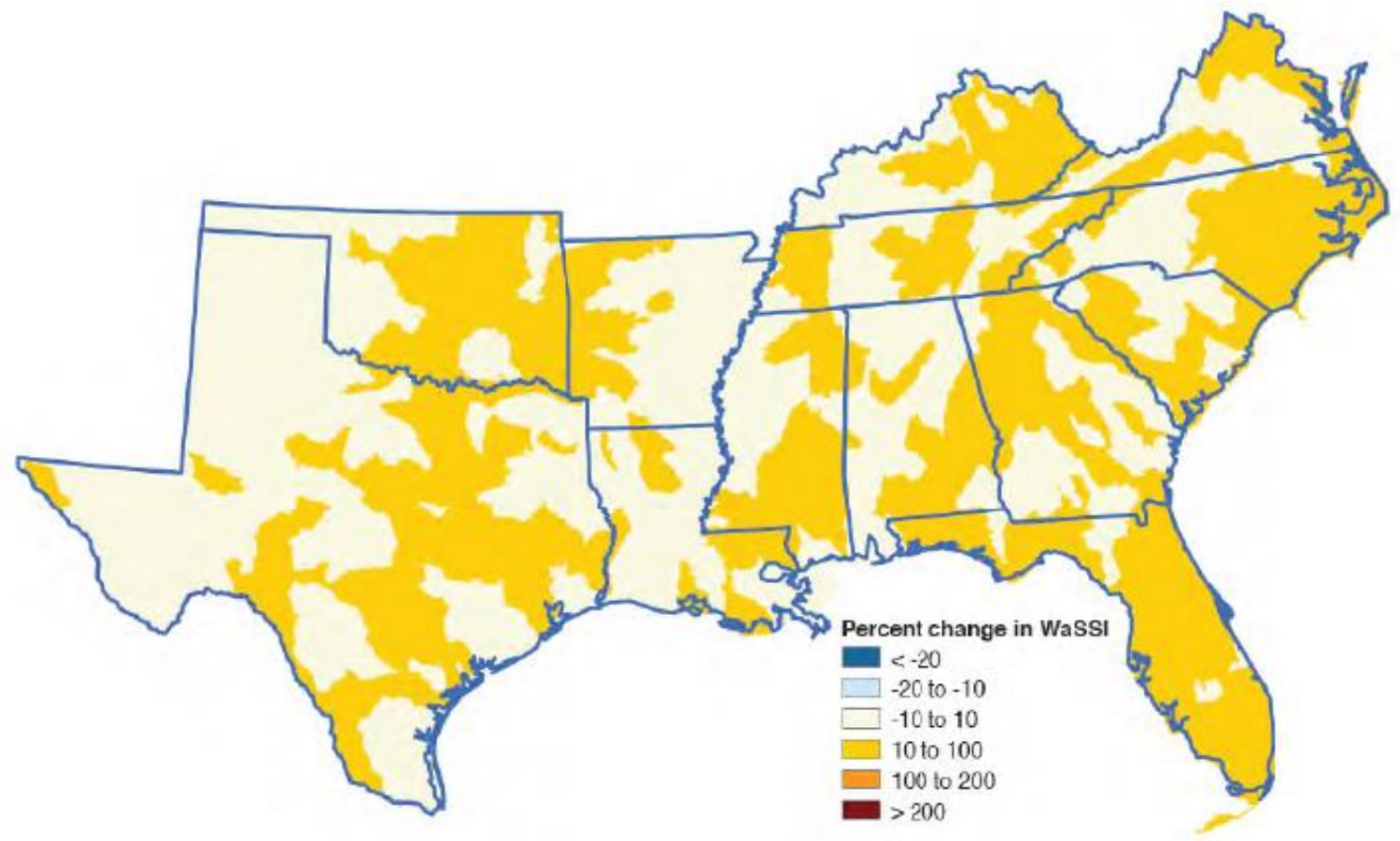

Figure 5. Water supply stress index as identified by the Water Supply Stress Index (WaSSI) and calculated as the ratio of total demand and total water supply. Values represent change in 2050 1334 1335 from current conditions, based on population projections. Adapted from Wear and Greis (2013). 


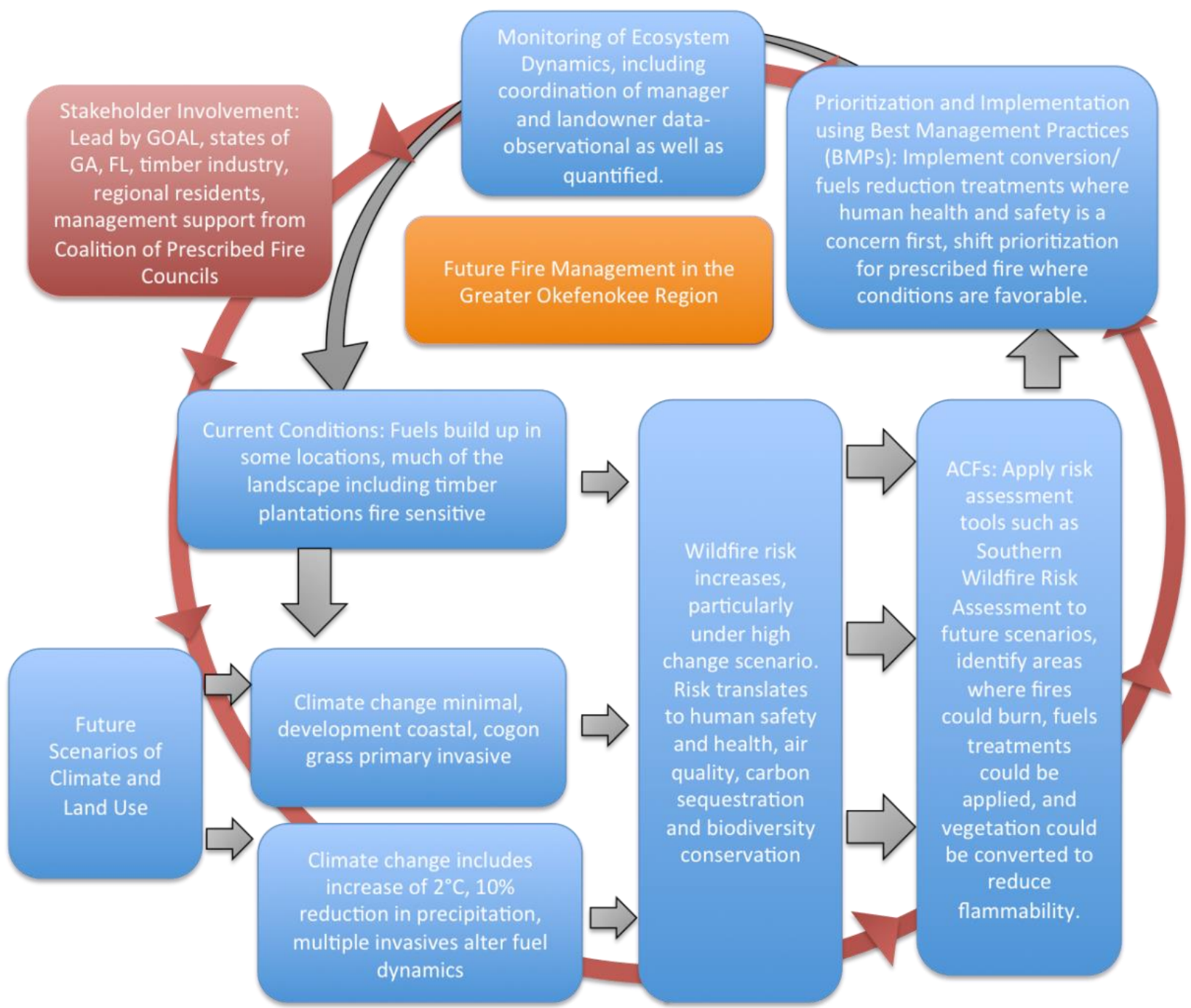

Figure 6. Application of conservation framework to fire management in the Okefenokee region of Georgia and Florida. Increasingly quantitative data could be incorporated as it becomes available. 


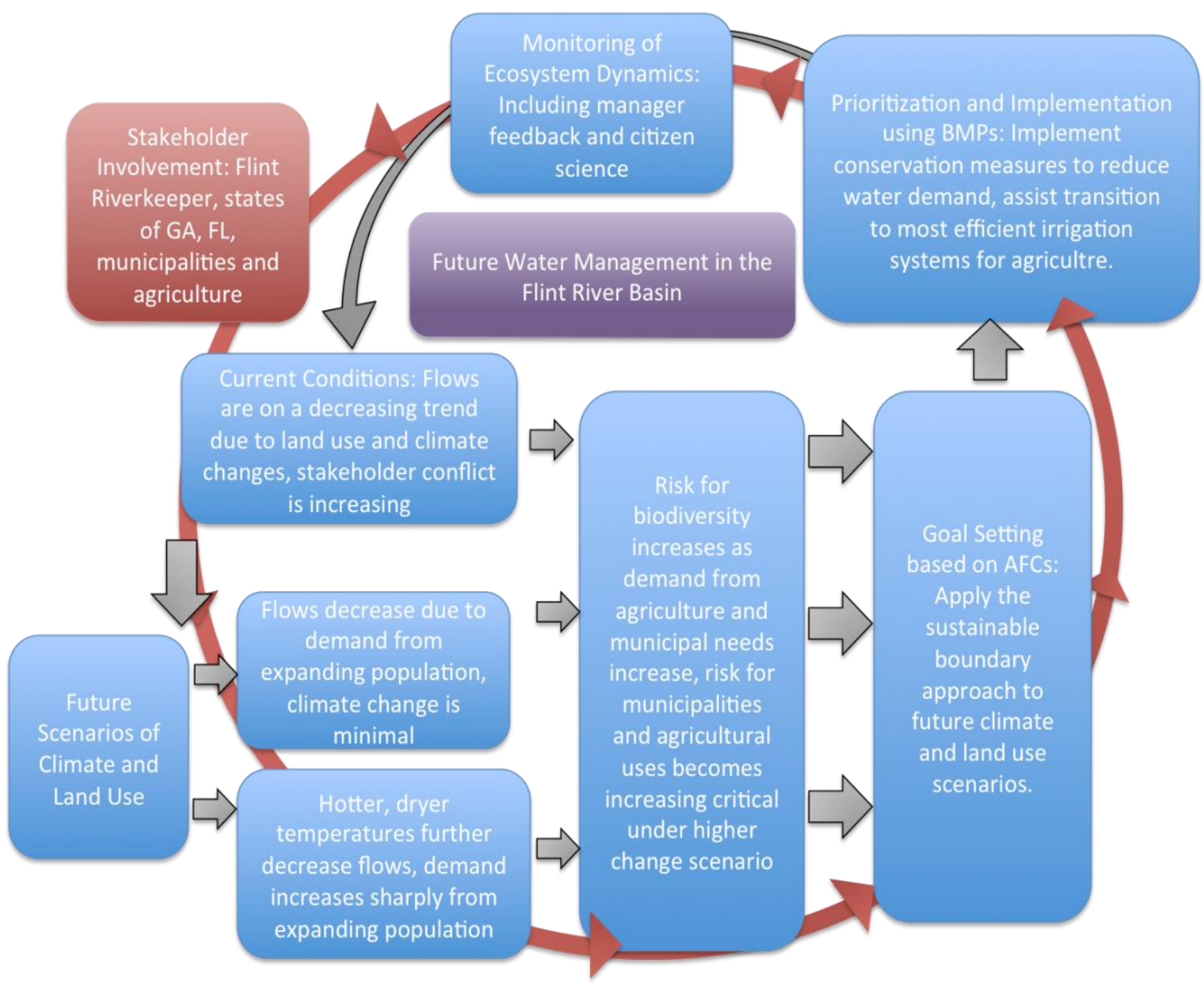




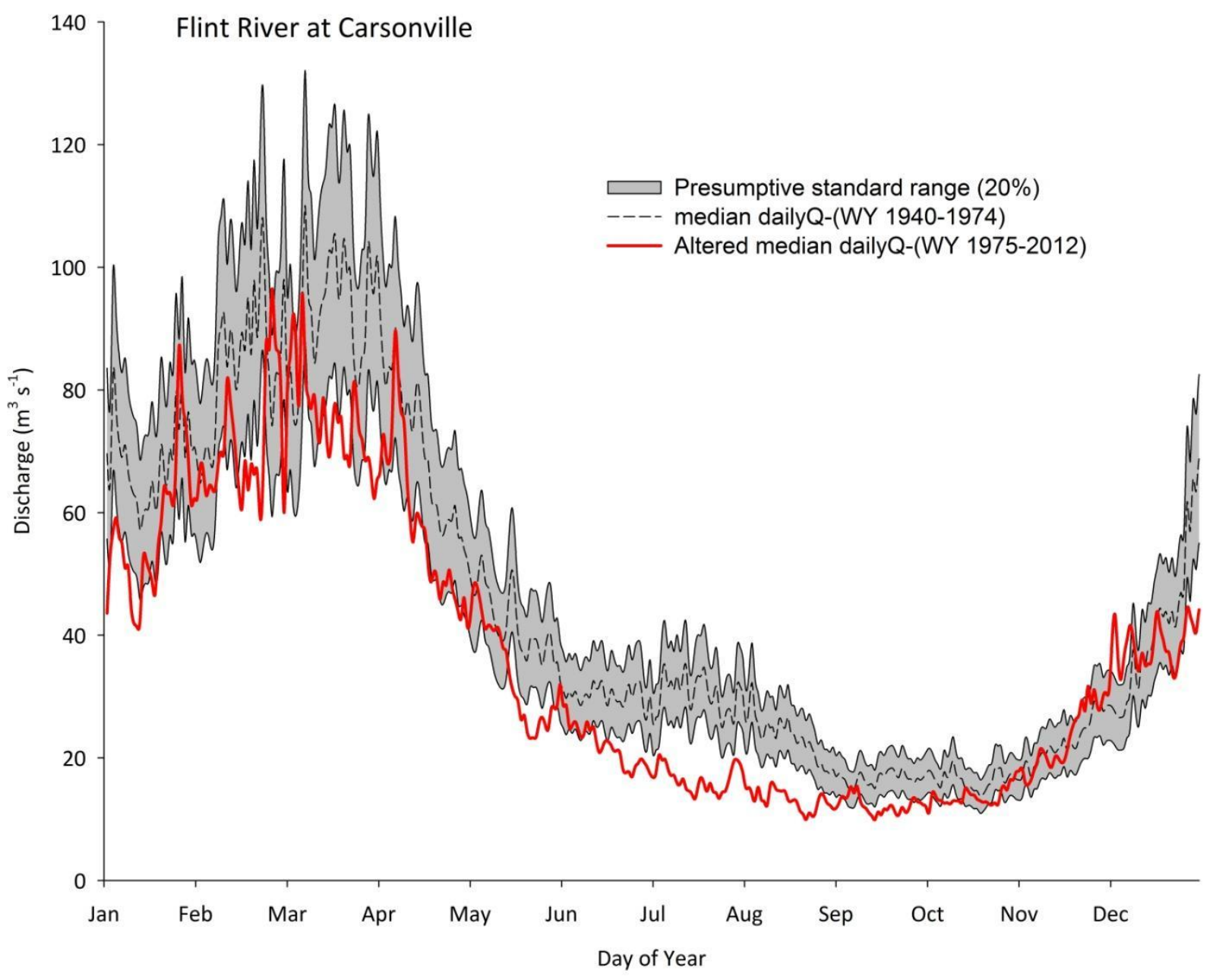

Figure 8. Calculation of Presumptive Standard using the SBA from Richter et al. (2011). Data obtained from the Carsonville, GA gauge (USGS 02347500). Grey range represents median daily flow $\pm 20 \%$. Solid red line represents 'altered' flow conditions based on median daily flows calculated from WY 1975 - 2012. 